\title{
Racial Reorganization and the United States Census 1850-1930: Mulattoes, Half-Breeds, Mixed Parentage, Hindoos, and the Mexican Race
}

\section{Citation}

Hochschild, Jennifer L., and Brenna Marea Powell. 2008. Racial reorganization and the United States census 1850-1930: mulattoes, half-breeds, mixed parentage, Hindoos, and the Mexican race. Studies in American Political Development 22: 59-96.

\section{Published Version}

http://dx.doi.org/10.1017/S0898588X08000047

\section{Permanent link}

http://nrs.harvard.edu/urn-3:HUL.InstRepos:3153295

\section{Terms of Use}

This article was downloaded from Harvard University's DASH repository, and is made available under the terms and conditions applicable to Other Posted Material, as set forth at http:// nrs.harvard.edu/urn-3:HUL.InstRepos:dash.current.terms-of-use\#LAA

\section{Share Your Story}

The Harvard community has made this article openly available.

Please share how this access benefits you. Submit a story.

\section{Accessibility}




\title{
Racial Reorganization and the United States Census 1850-1930: Mulattoes, Half-Breeds, Mixed Parentage, Hindoos, and the Mexican Race
}

\section{Jennifer L. Hochschild, Harvard University Brenna Marea Powell, Harvard University}

\begin{abstract}
Between 1850 and 1930, demographic upheaval in the United States was connected to reorganization of the racial order. Socially and politically recognized boundaries between groups shifted, new groups emerged, others disappeared, and notions of who belonged in which category changed. All recognized racial groups—blacks, whites, Indians, Asians, Mexicans and others-were affected. This article investigates how and why census racial classification policies changed during this period, only to stabilize abruptly before World War II. In the context of demographic transformations and their political consequences, we find that census policy in any given year was driven by a combination of scientific, political, and ideological motivations.

Based on this analysis, we rethink existing theoretical approaches to censuses and racial classification, arguing that a nation's census is deeply implicated in and helps to construct its social and political order. Censuses provide the concepts, taxonomy, and substantive information by which a nation understands its component parts as well as the contours of the whole; censuses both create the image and provide the mirror of that image for a nation's self-reflection. We conclude by outlining the meaning of this period in American history for current and future debates over race and classification.
\end{abstract}

The classification by race or color of individuals, or even entire populations, is not only very difficult, but is a very delicate matter to the United States Government.

—Census Director, 15 October $1936^{1}$

[The Census Bureau should be] the greatest statistical laboratory of the United States government, worthy to rank with the best statistical offices maintained by European governments.

- Secretary of Commerce and Labor, $1902^{2}$

Our thanks to Traci Burch and Vesla Weaver for their help; this article grows out of a book project co-authored by them and Jennifer Hochschild. Thanks also to K. Miya Woolfalk and Ariel Huerta for their excellent research assistance, to Rodney Ross for assistance at the National Archives, and to Margo Anderson, Daniel Carpenter, Nancy Foner, David Hollinger, Kenneth Prewitt, Jeffrey Strickland, and an anonymous reviewer for their very helpful suggestions for improvement.

1. Qtd. in Paul Schor, "Mobilizing for Pure Prestige? Challenging Federal Census Ethnic Categories in the USA (1850-1940)," International Social Science Journal 57 (2005): 99.

2. Qtd. in Hyman Alterman, Counting People: The Census in History (New York: Harcourt, Brace \& World, 1969), 232.
These figures are of little value.

-Census Population volume on number of quadroons, octoroons, and mulattoes, $1890^{3}$

Between the Civil War and World War II, the United States underwent a profound process of racial reorganization. Officially recognized group categories expanded and contracted; socially recognized boundaries between groups blurred and shifted; citizens and public actors passionately debated who belonged in which group. Basic components of the racial order were revised, revisited, and fundamentally altered. Such debates were highly consequential. While whites never lost their position at the top of the status hierarchy, who belonged in this privileged group was hotly contested. Whether or not a given group or individual was included in the category of "white" profoundly affected that group's or person's social standing. Blacks and Chinese were placed into

3. U.S. Census Office, Report on Population of the United States at the Eleventh Census: 1890 (Washington, DC: Government Printing Office, 1895), xciii. 
an ugly contest for the bottom of the status hierarchy, with the "victory" depending a great deal on how public officials defined and bounded the group. Simultaneously, whether American Indians were deemed assimilable, whether Mexican Americans should be subject to Jim Crow laws, and whether South Asians would be excluded along with Pacific-rim Asians all depended in part on whether they were classified in terms that allowed them to be potential insiders or that defined them as perennially outside the status of "American." Most broadly, over the course of almost a century, the U.S. government groped its way through extensive experimentationreorganizing and reimagining the racial order, with corresponding impact on individuals' and groups' life chances.

All branches of government and all levels of governance were involved to a greater or lesser degree in this process of racial reorganization. For reasons that we explain below, this article focuses on the crucial role of the Census Office (after 1902, the Census Bureau). ${ }^{4}$ Briefly put, we focus on the census because a nation's census is deeply implicated in and helps to construct its social and political order. Censuses provide the concepts, taxonomy, and substantive information by which a nation understands its component parts as well as the contours of the whole. A census both creates the image and provides the mirror of that image for a nation's self-reflection.

In the United States, the social and political order was largely defined by race. In fact, the process of simultaneously creating and reflecting group classifications was so important that by 1904, statistician Walter Willcox could correctly observe that "there is no country in which statistical investigation of race questions is so highly developed ... as in the United States." Highly developed it may have been-but the American approach to racial classification was also peculiar, reflecting the particularities of various experiments in racial classification. In any single year and across decades, racial categorization was internally incoherent, inconsistent across groups, and unstable. Mixture between blacks and others was identified, elaborated, and then dropped. Asians were racially identified through nationality, in finer and finer grained detail. Latin Americans were variously classified as white, mulatto, or racially distinct. Whites were elaborately distinguished by country of birth, "mixed parentage" (referring to parents' place of

4. Through 1900, the Census Office was newly convened every decade in order to conduct each census and produce the subsequent analysis and reports. Congress created the Census Bureau as a permanent government agency in 1902, upgrading its status at the same time.

5. Walter Willcox, "Census Statistics of the Negro," Yale Review 13 (1904): 274 birth) ${ }^{6}$ or mother tongue. In the only instance of racializing religion, immigrants from South Asia were combined under the "Hindoo" category. Native Americans were alternately ignored and categorized down to tiny fractions of black and white "blood."7

Then experimentation abruptly ceased. The 1930 census marked the last stage of the period of racial reorganization; after that year, the Census Bureau perceived only three races (white, Negro, Indian) and five Asian nationalities for many decades. It no longer explicitly identified racial mixture, ${ }^{8}$ mixed parentage, the Mexican race, Hindoos, fractions of Indian blood, ${ }^{9}$ or other innovative categories. After 1940 , it no longer used the term "color" in conjunction with "race." The United States entered World War II with the racial order established and the era of racial reorganization complete-until it started unraveling again toward the end of the twentieth century.

This trajectory raises two empirical questions to be pursued here: why was the Census Bureau's system of racial categorization so inconsistent and unstable, and why did experimentation in reorganizing the racial order begin and end when it did? Although others have recognized the importance of these questions, no one has as of yet systematically pursued their answers for all groups across the full time period, as we argue is essential for complete understanding. This analysis also raises broader theoretical questions about what censuses do, and why they matter politically: How do censuses relate to the ethnoracial order more generally? When and why do states count their populations by race, and why do these classification schemes take the particular forms that they do? What impact do classification systems have?

Our answer to the first empirical question, why this particular pattern of experimentation, focuses attention on the internal dynamics of a rather mysterious agency. We show below that three motivations interacted to produce officials' choice of categories for classifying a given group in a given year-contestation between Congress and the bureaucracy over political control, elected and appointed officials' commitment to scientific integrity, and the pull of ideological at sea.

6. Or even grandparents' place of birth, if the parent was born

7. After a first usage, often in quotations, we continue by using the terms common to the period about which we are writing. Following the same logic, we do not capitalize "negro" until the Census Bureau itself started to do so, in 1918.

8. According to Census Bureau lore, the "other" line added to the race question in 1910 served as the locus for "mixed race" enumerations until 1990, when it became primarily the site for Hispanics who did not identify with any of the United States' racial categories.

9. In 1950, the Census Bureau did measure fractions of Indian blood on a supplemental schedule used only on reservations. 
beliefs about race on the part of all actors. Sometimes these motivations reinforced each other; sometimes they were mutually constitutive; and sometimes they pulled in opposite directions from one another. In conjunction, they generated a set of categories that enabled the basic hierarchy of white supremacy and nonwhite subordination to be maintained, along with the distinction between actual or potential Americans and perennial outsiders, but that also led to great confusion about who nonwhites and outsiders were, how they would be defined in relationship to other groups, and how much they would be subordinated or excluded.

Our answer to the second empirical question, why this particular period saw such experimentation in creating a racial order, shifts our attention from the Census Bureau's internal actions to its external context. Although there are many plausible answers, we argue that they boil down to one: the politics of population change. The United States underwent extraordinary transformations geographically, demographically, institutionally, and politically between the Civil War and the Great Depression, and we will show how the Census Bureau, like all government offices, struggled simply to keep up, let alone to get control of the situation. For a variety of reasons, those changes ceased by 1930, and, with their demise, the impetus to change the census yet again also ceased.

Making sense of the process of racial reorganization in the United States requires a theoretical framework about the relationship between a census and the racial order that previous studies have not established. Thus we first set the stage for answering the empirical questions by considering more broadly how censuses help to create and solidify a modern polity's racial order. We build on existing literature to generate more systematic claims on that point. We then explore the dynamics shaping the U.S. Census Bureau's role in reorganizing the racial order from 1850 through 1930. We show how context and choice interacted in creating classifications of what is now understood as the ethnoracial pentagon (white, black, Asian, Native American, and Hispanic). ${ }^{10}$ Next, we consider why the period from 1850 through 1930 was especially important for developing the American racial order, and why experimentation in racial reorganization ended when it did. We conclude by moving back out to broader issues of what racial order was left in place after experimentation ended, what our analysis implies for the contemporary politics of racial classification in the United States, and what remains to be considered in future research.

10. The term is from David Hollinger, Postethnic America: Beyond Multiculturalism (New York: Basic Books, 2006).

\section{CENSUSES AND THE RACIAL ORDER}

\begin{abstract}
Border warfare of the most primitive type still is waged in mountain fastnesses, the darkest pages in the annals of crime now are being written, ... and from their factory prisons a hundred thousand children cry aloud for rescue. ... In hazardous scout duty into these fields of danger the Census Bureau leads. The Census is the sword that shatters secrecy, the key that opens trebly-guarded doors; the Enumerator is vested with the Nation's greatest right-the Right To Know-and on his findings all battle-lines depend. ${ }^{11}$
\end{abstract}

Despite valiant, if misguided, efforts to romanticize the role of a census bureau, it is not immediately obvious what political and substantive role a census plays in a polity. Professionals within a census bureau think of themselves as demographers, scientists intentionally removed from the hurly-burly and ambiguities of politics and policy-making. Census directors know that theirs is a political role, but a large part of their mission is to protect the appearance and reality of scientific neutrality. The directors may have been too successful; perhaps because the task of enumeration seems on its surface to be straightforward, political scientists have insufficiently theorized censuses. Thus it is necessary to begin with the big picture about how and why the United States census, and censuses in general, are intensely political actors.

How Does a Census Help to Shape the Racial Order? In almost every modern society that classifies its population, a census sits at the center of institutional expressions of the ethnoracial order. That order is constituted by a combination of ideological beliefs, both about one's own group and about others, and institutional and social practices, again both within and outside a given group. Together, beliefs and practices determine what the meaningful group categories are, how they are bounded, who belongs in each, and where each group's status is situated in relation to the others. The racial order helps to guide the polity's and individuals' choices about the distribution of goods and resources, and does a great deal to shape each person's life chances. We focus here especially on two dimensions of relative positioning in the American racial order: vertical or ranked hierarchy, and a horizontal dimension distinguishing insiders from outsiders. ${ }^{12}$

A census's system of racial classification does not by itself create the ethnoracial order; in fact, classification schemes are neither necessary nor sufficient tools for constructing and maintaining ethnoracial

11. Francis Rolt-Wheeler, The Boy with the U.S. Census (Charleston SC, BiblioBazaar, 2006 [1911]), Preface.

12. Claire Kim, "The Racial Triangulation of Asian Americans," Politics and Society 27 (1999): 103-36. 
hierarchy. On the one hand, countries such as France do not collect official statistics by race, but racial identity and stratification exist there nonetheless. ${ }^{13}$ In other countries such as Lebanon, the ethnoracial order is so fraught that ethnic or racial data are too contentious to collect or publish. Classification may be selective and applied only to particular groups, as distinguished from creating an entire classification system for the whole population. Most Latin American countries, for example, do not systematically categorize their populations by race, but some have census questions about membership in particular indigenous groups or ask about indigenous language use. ${ }^{14}$ Thus in Mexico, Colombia, and Peru, the census identifies the indigenous but not the African-descent populations. ${ }^{15}$ On the other hand, even an official classification system cannot create or sustain ethno-racial hierarchy without support from other social and political institutions. Classification alone will not transform an unranked ethnic order into a ranked one. ${ }^{16}$

Nevertheless, around the world, states increasingly count and categorize their populations according to ethnicity or race for purposes of public policymaking. ${ }^{17}$ And where they undertake such a task, the census is central. A modern census helps to construct and reconstruct an ethnoracial order in four ways: by providing the taxonomy and language of race; generating the informational content for that taxonomy: facilitating the development of public policies; and generating numbers upon which claims to political representation are made. Let us consider each in turn.

As many scholars have pointed out, censuses create the official language and taxonomy of race and imbue them with the authority of the state. Census

13. Erik Bleich, Race Politics in Britain and France: Ideas and Policymaking since the 1960's (Cambridge, UK: Cambridge University Press, 2006); Patrick Simon, "Ethnic Statistics: Fighting against Discrimination," presented at Social Statistics and Ethnic Diversity: Should We Count, How Should We Count, and Why?, Montreal, Quebec: 6-8 Dec. 2007.

14. Heather Layton and Harry Patrinos, "Estimating the Number of Indigenous Peoples in Latin America," in Indigenous Peoples, Poverty and Human Development in Latin America, ed. Gillette Hall and Harry Patrinos (New York: Palgrave Macmillan, 2005), $25-39$.

15. George Andrews, Afro-Latin America: 1800-2000. (New York: Oxford University Press, 2004).

16. Donald Horowitz, Ethnic Groups in Conflict, rev. ed. (Berkeley: University of California Press, 2000).

17. Ann Morning, "Ethnic Classification in Global Perspective: A Cross-National Survey of the 2000 Census Round" Population Research and Policy Review (forthcoming); Patrick Simon, "Ethnic" Statistics and Data Protection in the Council of Europe Counties (Strasbourg, France: Council of Europe, European Commission against Racism and Intolerance, 2007); Victor Thompson and Tahu Kukutai, "Inside-Out: The Politics of Enumerating the Nation," presented at Social Statistics and Ethnic Diversity: Should We Count, How Should We Count, and Why?, Montreal, Quebec: 6-8 Dec. 2007. racial policy defines the meaningful categories, locates boundaries between groups, assigns people to one category or another, and indicates which groups are subsets of or superordinate in relation to one another. 18 "Race" or "ethnicity" receive meaning in relation to other concepts such as color, nationality, classes of populations, language, place of birth, blood quantum, mother tongue, stock, or peoples. Are races more biologically fixed than ethnicities? Is mother tongue a truer representation of a person's identity than nationality or place of birth? Did the tiny colony of Ceylon really need seventy-eight nationalities and twenty-four races to identify its population, as the British apparently thought in their 1871 census of the island? ${ }^{19}$ What is meant in New Zealand when the proportion of respondents choosing "New Zealander" as their ethnicity on the census increases from 2 to 11 percent over five years? ${ }^{20}$ As we will see below, the terminology with which groups are labeled can contribute to determining their position and trajectory in a nation's racial order.

Second, a census then fills in its taxonomy. The census produces ostensibly objective data about the size of groups, as well as residential patterns, education, income, occupations, marital status, housing, age, and perhaps other characteristics such as religion, voting participation, or nativity and citizenship status. Many public and private actors may gather information about various groups-but the census is uniquely mandated to provide authoritative public information, and to do so on a scope and scale unmatched by other government institutions or private researchers. And as former census director Kenneth Prewitt points out, the information generated through censuses has a unique standing: "These are not matters of idle curiosity. Every question asked in the U.S. census connects to a specific government program or purpose."21

18. Kenneth. Prewitt, "A Nation Imagined, a Nation Measured: The Jeffersonian Legacy," in Across the Continent: Jefferson, Lewis and Clark, and the Making of America, ed. Douglas Seefeldt, Jeffrey Hantman, and Peter Onuf (Charlottesville: University of Virginia Press, 2005), 132-68; Valery Tishkov, "The Population Census and the Construction of Identity," Anthropology and Archeology of Eurasia 44 (2005): 10-40; Tom Moultrie and Rob Dorrington, "Used for Ill; Used for Good: A Century of Collecting Data on Race in South Africa," presented at Social Statistics and Ethnic Diversity: Should We Count, How Should We Count, and Why?, Montreal, Quebec, 6-8 Dec. 2007.

19. Kalinga Tudor Silva, "Politics of Ethnicity and Population Censuses in Sri Lanka," presented at Social Statistics and Ethnic Diversity: Should We Count, How Should We Count, and Why?, Montreal, Quebec, 6-8 Dec. 2007.

20. Tahu Kukutai and Robert Didham, "Can National Identity Become Ethnic Identity: The Case of the Emerging New Zealander Ethnic Group," presented at Social Statistics and Ethnic Diversity: Should We Count, How Should We Count, and Why?, Montreal, Quebec, 6-8 Dec. 2007.

21. Kenneth Prewitt, "Politics and Science in Census Taking," in The American People: Census 2000, ed. Reynolds Farley and John Haaga (New York: Russell Sage Foundation, 2005), 3. 
Third, a census can be used to facilitate public policies that reinforce or undermine a racial order. It does not in any simple sense cause these policies to come into existence, but it makes some more feasible and makes a few possible. Prewitt argues that "it would of course be an exaggeration to attribute the racialization of American politics to the census. But the availability of a racial taxonomy-counting and sorting by race-was handmaiden to the politics of race that continue to the present." In particular, "classification separated those entitled to full participation in society from those whose race was cause for exclusion." ${ }^{22}$ Congress used data from the 1890 census to set immigration quotas after 1924, and military leaders used 1940 census data to identify Japanese and Japanese American residents of the west coast for internment during World War II. ${ }^{23}$ One reason that the government of France refuses to collect racial and ethnic information is its determination that official data can never again be available to identify members of a particular group, as census data were used to round up Jews in Vichy France during World War II.

Information from a census may enable inclusive as well as exclusive policies. Census data were instrumental in implementing the 1965 Voting Rights Act in the United States, and they play a continuing role in litigating over affirmative action and employment discrimination and in other policies intended to disproportionately benefit disadvantaged groups. Activist groups in Brazil advocate changing how blacks are identified on the Brazilian census in part to facilitate the expansion of race-based affirmation action policies. $^{24}$

Fourth and finally, census data produce information upon which claims to political access and representation are made. From the Constitution's three-fifths clause for creating a Congress to the judicial mandate to reshape New York City's councilmanic districts in 1991, the location and magnitude of particular groups have affected how legislative districts are bounded and which legislators are chosen. $^{25}$ Data about groups' proportions may provide them with the ammunition against the state for new claims for representation; at the extreme end, proponents of consociational democracy advocate a form of ethnic proportional representation in

22. Prewitt, "A Nation Imagined," 152.

23. Margo Anderson and William Seltzer, "Challenges to the Confidentiality of U.S. Federal Statistics, 1910-1965," Journal of Offcial Statistics 23 (2007): 1-34.

24. Edward Telles, Race in Another America: The Significance of Skin Color in Brazil (Princeton, NJ: Princeton University Press, 2004).

25. Margo Anderson, The American Census: A Social History (New Haven, CT: Yale University Press, 1988); Reuel Rogers, "Race-based Coalitions among Minority Groups: Afro-Caribbean Immigrants and African-Americans in New York City," Urban Affairs Review 39 (2004): 283-317. divided societies that relies upon demographic data derived from censuses. ${ }^{26}$ A legislature's composition, in turn, affects adoption of policy choices connected to the racial order; those choices loop back to lend further aid to the construction of a self-defined group which can then mobilize and demand further action.

Why Does a Census Classify According to Race? Why would a state choose to use a census to classify its population according to race or ethnicity at all? Why might racial classification take a particular form? There is no clear and consistent answer except that virtually all scholars concur with Prewitt's starting point: despite demographers' fervent wish, "the categories made explicit by any classification scheme are seldom politically neutral." 27 Extant explanations of why censuses classify and how they arrive at a given taxonomy raise important considerations about domestic, international, and institutional contexts. However, in our view, none can fully explain the vast array of changes and experimentation that occurred on the U.S. census in the decades after 1850.

In one view, census classification is primarily a mechanism for racial control and exclusion-an instance of the broader claim that classification is part of the construction and maintenance of racial hierarchy and the distinction between insiders and outsiders. $^{28}$ Writing about Brazil and the United States, for example, Melissa Nobles traces the history of the mulatto category in order to demonstrate how race scientists within the Census Office (later Bureau) worked with southern politicians to produce census policy. The former sought to generate data supporting their theories of white biological superiority, while the latter sought evidence to justify and legitimate policies of non-white exclusion and white supremacy. ${ }^{29}$ Census-taking is thus an exercise in nation-building and state control-sometimes at the expense of subordinated groups. ${ }^{30}$ Taking this argument a step further, some perceive the census

26. Arend Lijphart, Democracy in Plural Societies: A Comparative Exploration (New Haven, CT: Yale University Press, 1977).

27. Prewitt, "A Nation Imagined," 139; see also Mae Ngai, "The Architecture of Race in American Immigration Law: A Reexamination of the Immigration Act of 1924," Journal of American History 86 (1999): 67-92; Melissa Nobles, Shades of Citizenship: Race and the Census in Modern Politics (Stanford, CA: Stanford University Press, 2000).

28. Loïc Wacquant, "For an Analytic of Racial Domination," Political Power and Social Theory 11 (1997): 221-34; David Theo Goldberg, Racial Subjects: Writing on Race in America (New York: Routledge, 1997); Rita Jalali and Seymour Martin Lipset, "Racial and Ethnic Conflicts: A Global Perspective," Political Science Quarterly 107 (1992): 585-606; Tukufu Zuberi, Thicker than Blood: How Racial Statistics Lie (Minneapolis: University of Minnesota Press, 2001).

29. Nobles, Shades of Citizenship.

30. Benedict Anderson, Imagined Communities: Reflections on the Origin and Spread of Nationalism (London: Verso, 1991). 
to be an arm of the Foucaultian state, always seeking to deepen its penetration and control of society through close and constant scrutiny. Thus adding the Chinese category in 1870 "was a form of surveillance, a mechanism for imposing order and racial clarity on the proliferation of an ambiguous alien."31

Considered through a different lens or in a different historical period, however, policies of racial classification might serve aspirational goals. The U.S. census provided the site of the multiracial movement's demands for official recognition in the 1990 s, $^{32}$ and invention of the category of "mother tongue" became the vehicle by which Jews could distinguish themselves from both blacks and Gentile whites many decades earlier. ${ }^{33}$ Neither a purely disciplinary nor aspirational account can explain the trajectory of change on the U.S. census between 1850 and 1930. Naomi Mezey acknowledges but does not try to reconcile the disciplinary and the aspirational roles of the census; Nobles does try by arguing that, in some historical moments, states actively impose racial categories on the population, while at others, states are relatively open to influence from social forces such as advocacy groups or changing norms and beliefs about race. She does not, however, specify when census policies will be top-down rather than bottom-up, or even how we would know.

David Kertzer and Dominique Arel provide one way to reconcile the two roles, through the idea of "the locus of power over the construction of identity categories in the census." 34 They argue that the locus of power at a given time depends upon the state's goals. Where state power is oriented towards coercion and control (as with censuses conducted by colonial countries in the colonies or by slave-owning nations), the locus of power lies with the state and it imposes categories as it sees fit. Conversely, where the state is oriented towards nation-building or incorporation of previously excluded groups into full societal membership, the locus of power shifts toward the groups subject to classification. In these cases, groups have more opportunity to negotiate with the state over the form that ethnoracial classification will take. As with the logics of discipline and

31. Naomi Mezey, "Erasure and Recognition: The Census, Race, and the National Imagination," Northwestern University Law Review 97 (2003): 1730.

32. Ibid.; Kim Williams, Mark One or More: Civil Rights in Multiracial America (Ann Arbor, MI: University of Michigan Press, 2006).

33. Victoria Hattam, Ethnic Shadows: Jews, Latinos, and Race Politics in the United States (Chicago: University of Chicago Press, 2007).

34. David Kertzer and Dominique Arel, Census and Identity: The Politics of Race, Ethnicity, and Language in National Censuses (Cambridge, UK: Cambridge University Press, 2002), 27; see also Jean-Louis Rallu, Victor Piché, and Patrick Simon, "Démographie et Ethnicité: Une Relation Ambigue," in Démographie: Analyse et Synthése, ed. Graziella Caselli, Jacques Vallin, and Guillaume Wunsch (Paris, France: Institut National d'Etudes Démographiques, 2004), 481-516. aspiration, the concept of locus of power in creating census racial categories is useful for explicating the American census, but it too does not quite suffice. For some groups between 1850 and 1930, the loci of power were multiple and rapidly shifting in ways Kertzer and Arel's model does not predict; groups such as Mexicans and South Asians were switched back and forth between agency and external control. Furthermore, none of the three logics explicated so far can explain the proliferation and then rejection of mixed race categories.

Two other strands of argument about how and why censuses create racial taxonomies contribute to explaining our case. Not only state and society, but also the international context, matters. International forces are increasingly important in determining the enumeration of race and ethnicity, given the interest of the United States and international bodies in securing standardized racial and ethnic data. ${ }^{35}$ For example, a report comparing "the collection of data to measure the extent and impact of discrimination" in five nations describes a European Community mandate for "the development and dissemination of comparable statistical series data on the scale of discrimination." "36 But such forces are not new; around the turn of the twentieth century, American classifications of migrants from Asia, Mexico, and much of Europe were shaped by both direct pressures from foreign governments and by the indirect consequences of wars and conquests.

Finally, although census taxonomies might be primarily political in one way or another, they are not only political. Stanley Lieberson reminds us of the "devilish principles" of census enumeration of race and ethnicity, especially the inherent disconnect between fluid and changing social reality and any fixed classification scheme. This disconnect is exacerbated by policy-makers' natural conservatism: "census-taking organizations are cautious and not readily inclined towards making changes in either the questions or their coded responses." 37 To the degree that this claim is persuasive, it makes the extraordinary degree of racial reorganization between 1850 and 1930 even more anomalous, and in need of explanation.

35. Morning, "Ethnic Classification in Global Perspective"; Thompson and Kukutai, "Inside-Out."

36. European Commission, Comparative Study on the Collection of Data to Measure the Extent and Impact of Discrimination within the United States, Canada, Australia, the United Kingdom and the Netherlands (Luxembourg: Office for Official Publications of the European Communities, 2004), 5.

37. Stanley Lieberson, "The Enumeration of Ethnic and Racial Groups in the Census: Some Devilish Principles," in Challenges of Measuring an Ethnic World: Science, Politics, and Reality, ed. Joint Canada-United States Conference on the Measurement of Ethnicity (Ottowa, Ontario: Statistics Canada and U.S. Department of Commerce, 1993), 26. 
Another important and nonpolitical influence on census taxonomies is the technological limits on what it is possible to ask, analyze, and report, and in how much detail. Our period of racial reorganization corresponded with a period of unprecedented growth and expansion in the technological capacity and budgetary resources available to the census. In 1790 the census boasted no permanent office staff and produced only one article-length report. By 1850 , it was a respectably institutionalized office reassembled every decade, and by 1910 it had acquired the status of a permanent bureau with a director of almost Cabinet-level rank. From 1850 through 1930, the number of enumerators per million residents of the United States (a rough indicator of quality) increased five-fold; the office staff, cost per capita, and number of published pages grew many times more. ${ }^{38}$ Technological capacity, as we will see below, may not correspond with human, organizational, or budgetary capacities. But without new technologies, many of the innovative schemes for racial and ethnic classification would simply not have been imaginable.

In short, ethnoracial taxonomies may emerge from a dominant group's racial ideology, the state's disciplinary control, subordinated groups' demands for inclusion and status, international pressures, bureaucrats' conservatism, technological feasibility, and policy concerns or the need for apportionment, according to the academic literature. We have no quarrel with any particular argument in this array; all of these approaches tell us something important about moments in the history of the American census between 1850 and 1930. Our quarrel is with the claim that any one of these characterizations is the best way to understand the relationship between a census and a nation's racial order. Only by understanding that the census can be, and has been, used by many actors for many purposes can we begin to make sense of its central role in reorganizing the American racial order between 1850 and 1940 .

\section{WHY A GIVEN TAXONOMY IN A PARTICULAR CENSUS?}

To supplement the array of extant explanations about why censuses create particular racial taxonomies, and to show why American census taxonomies were so incoherent, illogical, and unstable between 1850 and 1930, it is necessary to look inside the institution at the particular policy makers and policy decisions themselves. Within a given domestic and international context, bureaucratic and legislative actors make genuine, though constrained, choices about racial categorization. Their choices, we argue, result from an

38. Margo Anderson, ed., Encyclopedia of the U.S. Census (Washington, DC: CQ Press, 2000); see also A. Ross Eckler, The Bureau of the Census (New York: Praeger, 1972). unsystematic and fluid mixture of three motivationspolitical, scientific, and ideological. Over the ninety years of our study, these motivations sometimes reinforced, sometimes blurred into, and sometimes conflicted with one another, producing a set of results that can be explained retrospectively but whose contours could not be predicted $a$ priori. $^{39}$

By political, we mean two closely related phenomenathe desire for partisan advantage, and the desire of one institution to control or be autonomous of another. In particular, we examine the relationship between Congress and the Census Office (later, Bureau) in order to see how jockeying for the locus of power between the two bodies affected the racial categories used by enumerators in the field. ${ }^{40}$ By scientific, we mean the effort by agency analysts to produce results that warrant approbation from their professional peers. This motivation accords well with the desire for bureaucratic autonomy, but is likely to conflict with the urge to create or use data for partisan advantage. ${ }^{41}$ By ideological, we mean agencies' or politicians' desire to reinforce or act upon deep normative beliefs about the racial order, which may or may not be articulated or even in the consciousness of the actor. ${ }^{42}$ Ideologies can reinforce an agency's commitment to professionalism or undermine it. ${ }^{43}$ Ideologies may similarly reinforce partisan loyalties, or compete with them if a party is mainly a vehicle for jobs and spoils. $^{44}$

As the indeterminacy of that paragraph suggests, we believe it to be neither possible nor desirable to try to

39. William Petersen begins similarly, identifying four factors that jointly produce particular census policies: science, law (for apportionment and resource allocation), politics, and expediency, or "the constant effort to accommodate fiscal or technical restraints" (William Petersen, Ethnicity Counts [New Brunswick, NJ: Transaction Publishers, 1997], 71-72). He does not consider racial ideology.

40. For inter-institutional battles for control, see among many others, Daniel Carpenter, The Forging of Bureaucratic Autonomy: Reputations, Networks, and Policy Innovation in Executive Agencies, 18621928 (Princeton, NJ: Princeton University Press, 2001); Terry Moe, "Power and Political Institutions," Perspectives on Politics 3 (2005): 215-33; David Epstein and Sharyn O'Halloran, Delegating Powers: A Transaction Cost Politics Approach to Policy Making under Separate Powers (Cambridge, UK: Cambridge University Press, 1999); J. R. DeShazo and Jody Freeman, "The Congressional Competition to Control Delegated Power” Texas Law Review 81 (2003): 1443-519.

41. Scott Gates and John Brehm, Working, Shirking, and Sabotage: Bureaucratic Response to a Democratic Public (Ann Arbor, MI: University of Michigan Press, 1997); Theodore Porter, Trust in Numbers: The Pursuit of Objectivity in Science and Public Life (Princeton, NJ: Princeton University Press, 1995).

42. Clarissa Hayward, De-Facing Power (New York: Cambridge University Press, 2000); James Q. Wilson, Bureaucracy: What Government Agencies Do and Why They Do It (New York: Basic Books, 1989).

43. Herbert Kaufman, The Forest Ranger: A Study in Administrative Behavior (Baltimore, MD: Johns Hopkins University Press, 1960); John DiIulio, Governing Prisons: A Comparative Study of Correctional Management (New York: Free Press, 1987).

44. John Gerring, Party Ideologies in America 1828-1996 (Cambridge, UK: Cambridge University Press, 1998). 
predict when or how the three motivations will reinforce, mutually constitute, or contradict one another. That is a matter of historical contingency and of the peculiarities of a particular interaction. ${ }^{45}$ Nevertheless, understanding specific policy choices requires that we try to disentangle the three motivations. In so doing, we will show what happened both when the motivations coincided and when one superseded the others, thereby changing the direction of census classification or analysis.

A final prefatory note: just as the three motivations show no linear trend, so racial reorganization as a whole need not tend in one direction. Whether a change in classification schemes strengthens or attenuates group-based hierarchy or exclusion, or does both, is historically contingent. And given that racial boundaries and statuses are defined relationally, understanding changes in a polity's racial order requires simultaneous examination of all groups. That is our final complaint about the extant literature; most scholars have focused on one or two groups rather than on the whole system. ${ }^{46}$ Excellent research examines the purported racial science underlying interest in black-white mixture, ${ }^{47}$ or contestation over classifying European immigrants. ${ }^{48}$ Yet other research finds inconsistency in census

45. Here we follow the logic of Rogers Smith: the "multiple traditions approach holds that American political actors have always promoted civic ideologies that blend ... elements in various combinations. ... [L] aws have always emerged as none too coherent compromises among the distinct mixes of civic conceptions advanced by the more powerful actors in different eras" (Rogers Smith, Civic Ideals: Conflicting Visions of Citizenship in U.S. History [New Haven, CT: Yale University Press, 1997], 6).

46. Exceptions include William Petersen, "Politics and the Measurement of Ethnicity," in The Politics of Numbers, ed. William Alonso and Paul Starr (New York: Russell Sage Foundation, 1987): 187-233; Claudette Bennett, "Racial Categories Used in the Decennial Censuses, 1790 to the Present," Government Information Quarterly 17 (2000): 161-80; and Sharon Lee, "Racial Classifications in the US Census: 1890-1990," Ethnic and Racial Studies 16 (1993): 75-94.

47. Nobles, Shades of Citizenship; Heidi Ardizzone, "Red Blooded Americans: Mulattoes and the Melting Pot in U.S. Racialist and Nationalist Discourse, 1890-1930" (Ph.D. diss., University of Michigan, 1997); F. James Davis, Who Is Black?: One Nation's Definition (University Park: Pennsylvania State University Press, 2001); Christine Hickman, "The Devil and the One Drop Rule: Racial Categories, African Americans, and the U.S. Census," Michigan Law Review 95 (1997): 1161-265; Victoria Grieve, Any Perceptible Trace: Representations of the "Mulatto" in the United States Census, 18501920 (M.A. thesis, University of Georgia, 1996); Trina Jones, "Shades of Brown: The Law of Skin Color," Duke Law Journal 49 (2000): 1487-557.

48. Desmond King, Making Americans: Immigration, Race, and the Origins of the Diverse Democracy (Cambridge, MA: Harvard University Press, 2000); Joel Perlmann, 'Race or People': Federal Race Classifications for Europeans in America, 1898-1913 (Annandale-on-Hudson, NY: Levy Economics Institute, 2001); Hattam, Ethnic Shadows; Paul Schor, "Changing Racial Categories: The United States Bureau of the Census and Racial Minorities, 1900-1940," Organization of American Historians, St. Louis, Missouri: 30 Mar.-2 Apr. 2000. treatments of Hispanics or of Indians, ${ }^{49}$ and incoherence in the treatment of Asians. ${ }^{50}$

What is needed, and what we aim to contribute here, is examination of the dynamics of racial classification as a whole-across time and across groups. We turn to it now, by focusing on "snapshots" of crucial moments. Each snapshot demonstrates the mixture of motivations that led to a particular enumeration; taken together, they show how the categorizations of all groups collectively created and transformed a system of racial classification. Each snapshot also suggests how the dynamics of disciplinary control or aspirations for inclusion operated for a given group at a given period, and how technology, international pressures, and bureaucratic stickiness intermittently contributed to a particular classification scheme. By the time the reader has absorbed this set of snapshots, the narrative history of American racial reorganization around the turn of the twentieth century should be clear.

\section{BLACKS, WHITES, AND RACIAL MIXTURE}

The U.S. Census Office first addressed the racial order in response to the Constitution's mandate of a decennial "Enumeration" based on the principle that "Representatives and direct Taxes shall be apportioned among the several States ... according to their respective Numbers, which shall be determined by adding to the whole Number of free Persons, ... and excluding Indians not taxed, three fifths of all other Persons." Strictly speaking, the initial census takers needed only to distinguish free citizens from slaves (once Indians not taxed were excluded from enumeration). From the beginning, however, the census separated whites from "all other free Persons" as well as from slaves-thus building racial classification into the population counts needed for Congressional apportionment. The initial classification scheme remained in place with few changes for the nation's first half century.

Mulattoes in 1850: The law authorizing the 1850 census dramatically expanded the census's range. It

49. Clara Rodriguez, Changing Race: Latinos, the Census, and the History of Ethnicity in the United States (New York: New York University Press, 2000); José Hernandez, Leo Estrada, and David Alvirez, "Census Data and the Problem of Conceptually Defining the Mexican American Population," Social Science Quarterly 53 (1997): 671-87; Jorge del Pinal, "Treatment and Counting of Latinos in the Census," in The Latino Encyclopedia, ed. Richard Chabrán and Rafael Chabrán (New York: Marshall Cavendish, 1996).

On American Indians see William Seltzer and Margo Anderson, Excluding Indians Not Taxed: Federal Censuses and NativeAmericans in the 19th Century. Joint Statistical Meetings, Baltimore MD: 8-12 Aug. 1999; C. Matthew Snipp, American Indians: The First of This Land (New York: Russell Sage Foundation, 1989).

50. Martha Hodes, "Fractions and Fictions in the United States Census of 1890," in Haunted by Empire: Race and Colonial Intimacies in North American History, ed. Ann Laura Stoler (Durham, NC: Duke University Press, 2006), 240-70; Mezey, "Erasure and Recognition." 
called for statistics on agriculture, manufacture and industry, commerce, religion, crime, wages, and other topics. It required information on each person, rather than merely each household. And it required the federal marshals gathering these data to identify "mulattoes."

The reasons for enumerating mulattoes in 1850 are complex. The ideological context around any discussion of race was, as all readers know, intensely fraught. Secretary of State John C. Calhoun, for example, had sought to use 1840 census data to show that when freed, "the condition of the African, instead of being improved, has become worse." 51 He was referring to the fact that the 1840 census purportedly revealed that free blacks were overwhelmingly more likely to suffer from insanity and other disabilities than enslaved blacks or whites; controversy over these results roiled the House of Representatives and the new American Statistical Association for months.

In this loaded situation, Sen. Joseph Underwood (Whig-KY) urged questions to determine the "degree of removal from pure white and black races." He was probably influenced by Josiah Nott, the nation's pre-eminent racial theorist and polygenist. $^{52}$ Nott wanted census data in order to show that mixed-race people had poor fertility and short lives and to develop life insurance tables. ${ }^{53}$ In a classic case of the politics of strange bedfellows, northern opponents of slavery also sought detailed information about individual slaves-in Sen. William Seward's (Whig-NY) case, to find out "how rapid" was the "progress" of the African race in the United States. ${ }^{54}$

Other southern senators, however, insisted on deleting the question about degree of removal along with others that implicitly recognized slaves as persons with lives and histories (such as names, children born to female slaves, and place of birth). Race scholars' and abolitionists' mixed ideological and scientific desire for more data almost entirely lost out to the politicians' instinct to avoid feeding intractable ideological disputes. Nevertheless, after little discussion, Congress accepted the "Color" inquiry, specifying the categories of white, black,

51. Qtd. in Nobles, Shades of Citizenship, 33-34.

52. Reginald Horsman, Dr. Nott of Mobile: Southerner, Physician, and Racial Theorist (New Orleans: Louisiana State University Press, 1987).

53. Nobles, Shades of Citizenship; Anderson, The American Census. 54. Qtd. in ibid., 40-41. Diana Magnuson claims that the newly constituted Census Board, an advisory committee comprised mainly of eminent Northern statisticians, recommended adding "color" as well as "degree of removal from pure blood" to the slave schedule. She does not explain the Board's purpose, but nothing suggests that its members endorsed polygenicist racial science. So several streams may have fed the proposal to identify racial mixture. Diana Magnuson, "The Making of a Modern Census: The United States Census of Population, 1790-1940," (Ph.D. diss., University of Minnesota, 1995). and mulatto (identified by skin tone) for both free persons and slaves.

Nobles argues that identifying mulattoes brought Nott's theories of polygenesis and the degeneracy of racial mixture into the heart of the American statistical system. We agree; the new category implied the acceptability of such claims about racial rank order hierarchy, and imbued them with further ideological and scientific legitimacy. However, the new census category also opened questions about racial mixture to examination by ideologues of all sides; where southerners proposed enumerating mulattoes for reasons of profit or racial beliefs, northerners seized the opportunity to gather information about the slave system in order to promote emancipation or abolition. In the first of many such instances in the decades of racial reorganization, the ideological origins of particular classification schemes were buffeted by debate, resistance, and appropriation from competing normative commitments as well as by partisan and scientific motivations.

The debate over the mulatto category was part of a new effort to systematize census data collection. With the creation of a Census Board, 1850 marks the first time that Congress solicited, and subjected itself to, formal input from external expert advisors. ${ }^{55}$ Technological changes and the new discipline of statistics stood to revolutionize the enterprise of census-taking, and statisticians, industrialists, and politicians all clamored for data on an array of features of the growing American society. ${ }^{56}$ Congress thus required "radical changes in the method and scope of the census, ... constitut[ing] an epoch in the history of census taking." 57 Following the recommendations of the Census Board, Congress mandated data on agriculture, manufacture and industry, commerce, religion, crime, wages, and other topics. It required information on persons, not merely households. The number of inquiries on the census form rose from 7 in 1830 to 138 in 1850; questions on population alone increased from 7 to 22 over that same period. ${ }^{58}$ Thus some may have seen measuring racial mixture as just one more element in a more precise and accurate demographic portrait of the nation. ${ }^{59}$

55. Anderson, The American Census; Magnuson, "Making of a Modern Census."

56. Patricia Cohen, A Calculating People: The Spread of Numeracy in Early America (Chicago: University of Chicago Press, 1982); Theodore Porter, The Rise of Statistical Thinking, 1820-1900 (Princeton, NJ: Princeton University Press. 1986).

57. Carroll Wright and William Hunt, The History and Growth of the United States Census, Prepared for the Senate Committee on the Census (Washington, DC: Government Printing Office, 1900), 47.

58. Ibid., 87. Forty years later, census superintendent Francis Walker described "the continually expanding detail into which the traditional classes of statistics will inevitably be drawn, under the ever-growing popular demand for local and minute information" (Francis Walker, "The Eleventh Census of the United States," Quarterly Journal of Economics 2 [1888]: 136-37).

59. An official census history, for example, downplayed the role of ideological and partisan dispute in 1850 in favor of procedural 
In short, "mulatto" arrived on the census as the stalking horse for polygenist racial science, as a way for opponents of slavery to learn more about blacks, as one piece of the statisticians' omnivorous quest for knowledge, as the lesser of many evils to southern politicians, as an acknowledgement of increasing racial mixture and the distinctive economic and social position of many mulattoes, ${ }^{60}$ as a chip in the battle over Congressional control of executive agencies, and as an element of partisan contestation. ${ }^{61}$ Politics, science, and ideology were inextricably mixed, and the process of racial reorganization was underway-arguably not exactly as anyone intended. $^{62}$

Quadroons and Octoroons in 1890: Despite vast changes in the American racial order between 1850 and 1880 , the next three censuses produced no revision of the mulatto category (although in 1880, for budgetary reasons, the Census Office published no data on mulattoes). The reason was probably the simple fact of bureaucratic stickiness. In 1890, however, the census again dramatically expanded in size, scope, and budget. It now boasted a centralized office, led by a network of sophisticated statisticians and social scientists determined to wrest control from supporters of political patronage for hiring enumerators, and to vest the census with scientific legitimacy. As Superintendent Robert Porter informed his boss, the Secretary of the Interior, "The demand for exact statistics is constantly increasing, [as is] ... the importance of greater accuracy and care in securing statistical data of all

and scientific motivations: "The focal point of the debate was what level of detailed information to gather about slaves, but the debate became a debate on the census itself and what was the proper reach of the federal government. At the same time, new questions were asked that gathered information about schools, crime, churches, and pauperism" as well as about birthplace of the householder and his or her parents (General Accounting Office, Decennial Census: Overview of Historical Census Issues [Washington, DC: Government Printing Office, 1998], 21).

60. Joel Williamson, New People: Miscegenation and Mulattoes in the United States (New York: Free Press, 1980); Howard Bodenhorn, "The Mulatto Advantage: The Biological Consequences of Complexion in Rural Antebellum Virginia," Journal of Interdisciplinary History 33 (2002): 21-46; Bodenhorn and Christopher Ruebeck, "Colorism and African-American Wealth: Evidence from the Nineteenth-Century South," Journal of Population Economics 20 (2007): 599-620.

61. On disputes over institutional prerogatives and apportionment, see Anderson, The American Census.

62. After all of the debate, the 1850 Population report made little use of the mulatto category and contained very little information about mulattoes, except for one brief but highly pejorative footnote by Superintendent Kennedy. The report explained the paucity of information bureaucratically - the data "not having been prepared when the other facts on population were being tabulated, could not now be presented in greater detail without expense and delay" (U.S. Census Office, The Seventh Census of the United States: 1850 [Washington, DC: R. Armstrong, 1853], 63). kinds."63 Cutting-edge technology, including the wonder of mechanized tabulation, introduced new possibilities for collating and analyzing data; the 1880 and 1890 censuses generated well over 20,000 published pages each, compared with less than 3,500 in 1870 .

As in 1850, the expansion included more detail on racial mixture. With regard to "color or race," enumerators' instructions specified:

\begin{abstract}
Be particularly careful to distinguish between blacks, mulattoes, quadroons, and octoroons. The word "black" should be used to describe those persons who have three-fourths or more black blood; "mulatto," those persons who have from three-eighths to five-eighths black blood; "quadroon," those persons who have one-fourth black blood; and "octoroon," those persons who have one-eighth or any trace of black blood. ${ }^{64}$
\end{abstract}

No instruction explained how to determine fractions of black blood. ${ }^{65}$

The proximate reason for this new instruction is reasonably clear, and similar to that of 1850; even this greatly expanded Census Office had relatively little autonomy and took direction from specific Congressional mandates. Rep. Joseph Wheeler (D-AL) proposed in 1888 that data be collected "to ascertain and exhibit the physical effects upon offspring resulting from the amalgamation of human species." The census should therefore "publish the birth rate and death rate among pure whites, and among negroes, Chinamen, Indians, and half-breeds or hybrids of any description or character ... as well as of mulattoes, quadroons, and octoroons."66 Congressional records say nothing of Wheeler's purpose. However, Carroll Wright, the Commissioner of Labor and acting census superintendent in the late 1880s, supported the inquiry, arguing that "whether the

63. Annual Report of the Secretary of Interior. 51st Cong. 2nd Sess., House Exec. Doc. 1 (Washington, DC: Government Printing Office, 1889), 2724; qtd. in Magnuson, "Making of a Modern Census," 8. See App. Table A2 for information on the expansion of the scope of the census since its inception.

64. U.S. Bureau of the Census, Measuring America: The Decennial Censuses From 1790 to 2000 (Washington, DC: Government Printing Office, 2002), 27.

65. As one reader of this article has commented, the silences in the historical record sometimes speak as loudly as the spoken or written word. This is one of those occasions; we have no information on why there were no clear instructions to enumerators on how to determine fractions of black blood. Perhaps the Census Office assumed that everyone was practiced in distinguishing fractions of black blood, or it was so hostile to this Congressional mandate (see below) that it simply refused to waste any unnecessary resources on an impossible task. Analysis of the 1890 census is made more difficult by the fact that most of the original schedules for that year were later destroyed in a fire (Anderson, The American Census).

66. U.S. House of Representatives, 50th Cong., 1st Sess., H.R. 11036, A Bill to Ascertain and Exhibit the Physical Effects Upon the Offspring Resulting from the Amalgamation of Human Species (Washington, DC: Government Printing Office, 1888), 1. 
mulattoes, quadroons, and octoroons are disappearing and the race becoming more purely Negro, is a question which can not be settled by observation. It must be settled by statistics, and the sooner the statistics are collected the better." Neither house of Congress discussed the addition, merely noting that this addition would be "inexpensive" and was "desired by scientists." 67

Ideology surely underlay this curious one-time experiment in measuring the finer gradations of racial mixture; race scientists continued their perennial interest in showing that mixed-race individuals were physically, mentally, and morally degenerate. At the same time, the late 1880 s were a period of efforts to consolidate white supremacy in the south after losing the Civil War and resisting Reconstruction. White domination was not as settled during this time as it retrospectively appears to have been; there were pockets of genuine contestation over racial hierarchy, and some blacks still held political office and a little political power. ${ }^{68}$ Given its unsettled state, authorities presumably wanted to know how much the racial hierarchy needed to be further reinforced, which depended in part on whether the number of people blurring the line between the subordinated and the dominant races was increasing or decreasing, thriving or struggling, moving toward or away from whiteness.

Nevertheless, as in 1850, ideology does not completely explain the addition of quadroon and octoroon. Wright himself stressed the need for "accurate information-as full as possible" and "statistical information" on a "question which can not be settled by observation." 69 Those are the words of someone seeking the facts, or at least of someone who understands that seeking the facts is the best justification for gathering information to support an ideology.

Nor did the Census Office evince any ideological passion about the data themselves. The 1890 Population report barely mentioned the racial hybridity data except to dismiss them. One table in the 1,000-page volume distinguished all four subsets of negroes, yet offered no commentary. The intensely detailed analysis of changing racial proportions in each state was couched entirely in terms of whites and negroes. What census officials did do with these data was disavow them. Former Superintendent Robert Porter's introduction to the Population volume was crystal clear on this topic:

67. Qtd. in Nobles, Shades of Citizenship, 58; see also Ardizzone, "Red Blooded Americans," 188.

68. C. Vann Woodward, The Strange Career of Jim Crow, 2d rev. ed. (New York: Oxford University Press, 1971); Jane Dailey, Glenda Gilmore, and Bryant Simon, eds. Jumpin' Iim Crow: Southern Politics from Civil War to Civil Rights (Princeton, NJ: Princeton University Press, 2000).

69. Qtd. in Nobles, Shades of Citizenship, 57-58.
The persons of negro descent are further classified under the law, as follows: negroes, $6,337,980$; mulattoes, 956,989; quadroons, 105,135; and octoroons, 69,936. These figures are of little value. Indeed, as an indication of the extent to which the races have mingled, they are misleading. ${ }^{70}$

Porter later observed that "no one, I think, can realise [sic] the importance of a simple schedule more than I do.... Yet the failure ... to realise the ideal [in the enormously complex 1890 census] was a conspicuous failure." His "ideal population schedule" would include merely ten brief questions; with regard to race it would inquire only whether the person was "white, black, Chinese, Japanese, or Indians [sic]."71

As Porter's repudiation suggests, the new racial classification arguably did less to solidify the ideological commitment to a stratified racial order than to open that commitment to scrutiny by people with alternative ideologies or a competing allegiance to scientific rigor. Many leading social scientists concurred with Porter that measuring fine inter-racial gradations was a waste of time. Eminent statistician Richmond Mayo-Smith, to cite only one example, wrote that "the extension of the colour division to quadroon and octoroon seems to me entirely futile, because the persons interested (belonging to the old slave class or their descendents) will never be able to say how much white blood flows in their veins, and to determine the question by the shade of colour of the individual would be contrary to our knowledge of physiological laws."72 Most experts simply ignored the new categories of racial mixture. ${ }^{73}$

In fact, census officials and their supporters were clearly annoyed by this Congressional imposition. Porter pointedly noted that "the persons of negro descent are further classified under the law, as follows." 74 Being outside the government, MayoSmith permitted himself more directness:

Additions are made to the [census] schedules by Congress, but they are either for political

70. U.S. Census Office, Report on Population of the United States at the Eleventh Census: 1890 (Washington, DC: Government Printing Office, 1895), xciii.

71. Robert Porter, "The Eleventh United States Census," Journal of the Royal Statistical Society 57 (1894): 655.

72. Richmond Mayo-Smith, "The Eleventh Census of the United States." The Economic Journal 1 (1891): 46, 48.

73. One prominent commentator found the important innovations of the 1890 census to be the "electrical tabulating machine" and "statistics on the number and amount of mortgages" (328-29)."The United States Census of 1890," Journal of the Royal Statistical Society. 55 (1892): 328-29 (no author). To Porter, its "most striking feature" was authorization to hire expert statisticians to supervise and write the special reports-a political claim about seeking autonomy from Congress and other interferences and a scientific bid for professional legitimacy (Porter, "The Eleventh United States Census," 644).

74. Ibid. (Emphasis added). 
effect or are due to momentary interest in a particular question, and they are often forced upon the superintendent without regard to their permanent usefulness or to the danger of over-burdening the enumerators. ${ }^{75}$

Given, for the first time, no explicit instructions from Congress on population enumeration in 1900 , the Census Office did what Porter had long wanted, and dropped all indicators of black-white racial mixture.

Thus political control by Congress and the ideology of racial science combined to produce the census's multiple measurements of racial mixture in 1890 . The desire for statistical precision underlay the subsequent disavowal of such a socially constructed hodgepodge, and growing bureaucratic autonomy combined with the desire for statistical precision to permit abandonment of any such measurement a decade later. Quadroon and octoroon remain in the historical record only as a failed experiment even though, as the new century approached, the American racial order remained unsettled on the question of whether mixed-race individuals were importantly different from their single-race counterparts.

The Disappearance of Mulatto in 1930: While Congress never again asserted itself on the mulatto category, actors within the Census Bureau did. In 1910, Walter Willcox, a Cornell University statistician and potent force within the Census Bureau, argued to reinstate the mulatto category on the grounds that a "simple" question asking only if the person were of "pure or mixed blood" would be sufficiently accurate to provide valuable information. ${ }^{76} \mathrm{He}$ temporarily won the day; "mulatto" was returned to the census in 1910, and again in 1920, after which it disappeared.

Why did the mulatto category disappear? The Census Bureau once again relied on science for its explanation: "The principal reason for giving up the attempt to separate blacks and mulattoes was the fact that results of the attempt in past censuses had been very imperfect" and "not even approximately accurate." Despite all their efforts at precision, the mulatto increase of 1910 "was probably the result of the employment of large numbers of Negro enumerators and ... this might explain the decrease in the percentage mulatto between 1910 and 1920."

Congress's 1929 Act providing for the 1930 census ceded control over the content of specific questions to the Census Bureau, so it was officially free to choose its path. ${ }^{78}$ However, its scientific explanation

75. Richmond Mayo-Smith, "On Census Methods," Political Science Quarterly 5 (1890): 260.

76. U.S. Bureau of the Census, Special Reports: Supplementary Analysis and Derivative Tables: Twelfth Census of the United States, 1900 (Washington, DC: Government Printing Office, 1906), 189.

77. National Archives, Record Group 29, folder Advisory Committee 12/14 and 15, 1928 (hereafter RG 29).

78. Eckler, The Bureau of the Census. for dropping mulatto in 1930 is at best only partial. After all, census officials had complained for decades that counts of racial mixture were very imperfect-so why the change then? The broader context suggests the importance of changing ideologies about the racial order, on the part of both whites and blacks. A crucial clue is the fact that the Census Bureau's deletion of attention to racial mixture after almost a century caused not even a ripple within Congress, the press, or the academy. The change was a nonissue, a policy decision reflecting new normative commitments, new laws, and a new conceptualization of the racial order. By 1930, the American ideology of white supremacy had reversed course from the turn of the century's fascination with racial mixture; southern states' recently instituted one-drop-of-blood rules were migrating into federal statistical systems. Scholarly attention to racial mixture continued into the 1930s, and mixture never stopped being socially and economically salient in black communities. ${ }^{79}$ But mainstream ideology had shifted to a commitment to bright-line differences between races in order to maintain white racial purity. The 1930 census reflected and solidified that shift. ${ }^{80}$

Blacks were also increasingly committed to a move from blurred to rigid boundaries, albeit for different reasons. Although a significant segment of lightskinned blacks continued to affirm the distinctive classification of mulatto, many black leaders had long claimed that distinguishing blacks from mulattoes was conceptually mistaken and destructive of solidarity. W. E. B. Du Bois, for example, had urged census officials in 1900 to "class those of African descent together," and to accept an expert advisory panel that included Booker T. Washington and Kelly Miller, a prominent black sociologist. ${ }^{81} \mathrm{Du}$ Bois

79. Edward Reuter, "The American Mulatto," Annals of the American Academy of Political and Social Science 140 (1928): 36-43; Robert Park, "Mentality of Racial Hybrids," American Journal of Sociology 36 (1931): 534-51; E. Franklin Frazier, "Children in Black and Mulatto Families," American Journal of Sociology 39 (1933): 12-29; Melville Herskovits, "A Critical Discussion of the "Mulatto Hypothesis'," Journal of Negro Education 3 (1934): 389-402; Everett Stonequist, "Race Mixture and the Mulatto," in Race Relations and the Race Problem: A Definition and an Analysis, ed. Edgar Thompson (New York: Greenwood Press, 1939): 246-68.

80. As always, space limitations affected decisions about what to ask on the population schedule and how to ask it. In 1930 there was space available on the punch cards for 11 race or color options [ for details and images, see (Truesdell 1965)]. Margo Anderson argues (note to authors, 24 Jan. 2008) that the introduction of "Mexican" squeezed the mulatto category out. However, a new "Hawaiian" category appeared on the punch cards at the same time; if mulatto had retained social and scientific significance, it is unlikely that the (relatively tiny) Hawaiian category would have been allowed to supersede it.

81. W. E. B. Du Bois, "The Twelfth Census and the Negro Problems," The Southern Workman 29 (1900): 307. The Census Office took Du Bois seriously, judging by the fact that it commissioned him shortly thereafter to compile and analyze census data on the state of black agriculture (U.S. Census Office, Bulletin 8, Negroes in 
chose his list of experts carefully; both Washington and Miller advocated black unity and erasure of the line between blacks and mulattoes. ${ }^{82}$

Similar views might have found expression within the Census Bureau. Statistician Charles E. Hall, a close friend of Miller, worked at the bureau for four decades. He rose to become the "Specialist in Negro Statistics" and the highest ranking black public official in the nation's capital; the black press labeled him "The Most Important Washington Negro." ${ }^{83}$ We found no direct evidence of Hall's connection with the mulatto category, but he worked indefatigably to shift the bureau's focus from monitoring and control of the black community through data collection to direct service to it in order to foster greater inclusion. His reports emphasized blacks' progress through increased literacy, professional employment, and purchasing power; he vigorously and publicly opposed segregation in federal agencies and his own unfair treatment with regard to promotion and salary. ${ }^{84}$ Given his racial pride, he probably opposed the mulatto category. His major report on Negroes in the United States: 1920-1932 included no mention of mulattoes, in sharp contrast to the 1918 volume's full chapter on mulattoes to which the later volume was intended to be "supplementary."

In sum, "mulatto" rose, effloresced, and disappeared through a combination of ideology, politics, and science. Ideological contestation over slavery merged with Congress's assertion of control over the Census Office and the first stirrings of both racial and demographic science to bring racial mixture onto the census. Four decades later, Congress retained control over an increasingly restive and stronger Census Office-enough control so that ideological anxiety about racial boundary-blurring and the robust racial "science" now known as eugenics was able to have even more impact on census

the United States [Washington, DC: Government Printing Office, 1904]).

82. H. L. Mencken later claimed that it was Washington who persuaded the Census Office to drop mixed race categories after 1890 and to "beg[in] calling all colored persons of African blood Negroes" (H. L. Mencken, "Designations for Colored Folk," American Speech 19 [1944], 170, emphasis in original). Miller frequently castigated white race scientists as well as the Census Bureau's bungled efforts to collect data on racial mixture on the grounds that "the dual caste system is undemocratic and un-Christian enough; to add a third would be inexcusable compounding of iniquity" (Kelly Miller, "Review of The Mulatto in the United States," American Journal of Sociology 25 [1919]: 220).

83. Rienzi Lemus, "Chas. E. Hall Rated The Most Important Washington Negro," Richmond Planet 8 Jan. 1938; Lemus, "Most Important Negro In Black Cabinet Is Charlie Hall in Dept. of Commerce," (Oklahoma City, OK) Black Dispatch, 8 Jan. 1938.

84. In Charles E. Hall papers, from the personal collection of Rodney Ross, Archivist, National Archives; see also Desmond King, "The Racial Bureaucracy," Governance 12 (1999): 345-77. categories. But the Census Office fought back, in part to promote autonomy from Congressional patronage-mongers and in part because it was increasingly committed to demographic rigor, which efforts to measure racial proportions through appearance violated. By 1930-when whites' ideology of racial hierarchy had shifted from obsession with racial mixture to official denial of its existence, when state legislatures had finally sorted out how to implement one-drop laws, and when most black elites concurred in preferring bright lines to blurred onesexperimentation with various categorizations in the black-white racial order ended in a reorganized and drastically simplified hierarchy.

The upshot was a major component of a redefined racial order. After the upheaval of civil war and emancipation, the census helped Americans to decide who was to be defined as black or white and what was entailed by a given definition. It gave Americans the information they needed to realize that black and white are continual rather than nominal categories and that racial boundaries are defined rather than discovered. Once Americans got a good look at that idea, they turned their back on it, in favor of legally mandated distinctions between groups that were now officially mutually exclusive. For the rest of the twentieth century, the classification system of the Census Bureau reinforced the black/white binary prescribed in 1930.

\section{CHINESE, JAPANESE, HINDOOS, AND ASIATICS}

Racial classification was even more vexed with respect to Asian immigrants, who began arriving on the west coast just prior to the Civil War. The census reflected the nation's perplexity and anxiety about this population, and provided the categories according to which the government eventually resolved it. For Asians, the crucial issue was not racial mixture but rather the deeper question of what a race actually is, and who would be allowed to join the insiders of American society rather than being excluded or remaining on the margins as perennial foreigners.

Chinese, Sometimes Including Japanese: Census recognition of people who are today seen as Asian American first appeared in the extra California state census of 1852, in which a subset of the white population was identified in a footnote as Chinese. (A fire had destroyed some census forms, so California received a second enumeration.) The 1860 Population report noted that Chinese were included with whites in several state tabulations, but "Asiatics" were tabulated separately only in the state of California. In 1870 "Chinese" appeared as a color on the main population schedule, along with White, Black, Mulatto, and 
Indian. 85 "Chinese," the 1870 Population report helpfully noted, "for census purposes was held to embrace Japanese . . . but to exclude Hawaiians." 86

Asian nationalities, along with blurred boundaries among them, continued to appear at irregular intervals over succeeding decades. By 1920 enumerators were told to distinguish among Chinese, Japanese, Filipino, Hindu, Korean, and Other (along with White, Black and Mulatto), and publications added categories such as Asian Hawaiians, part Hawaiian, "Mixed (rather than Chomorro or Polynesian)," and "Mixed (rather than Filipino)." Census officials never explained why enumeration of these groups was always based on nationality or racial mixture, rather than a supra-national racial category like "Asiatic" or "Mongolian," in the common terminology of the day. Only the 1880 Population report includes a brief reference to Asiatics as a racial group including various nationalities. Nor did Congress ever mention Asiatics or any Asian nationality in any census law in any year. (Congress was without question interested, however; as a Congressional report on changes to the 1870 census observed rather cryptically, "That [inquiry] relating to color has been made to include distinctively the Chinese, so as to throw some light on the grave questions which the arrival of the Celestials among us has raised.") 87

As with immigrants from Europe (see below), the initial inconsistency and confusion on the census might be explained by the inconsistency and confusion in other official domains. Congressional hearings, for example, show an endless variety of locutions-Hindostanic Bengalese, Mongolian and Chinese as racial synonyms, Chinese as a subset of Mongolian, Chinese and Asiatic as synonyms, "Hindoos and other Asiatic races" in contrast to the Chinese, Orientals, and the red, black, and yellow races, among others.

If the taxonomy was confused, the racial ideology was not. Politicians' debate over Asians revolved around whether any or all could ever move from the status of perennial foreigners and outsiders, to that of assimilable immigrants. The Republican party initially took the latter position, as did former census director Joseph Kennedy. In 1875, he spoke at great length and with deep passion about "so monstrous a proposition" as the Chinese exclusion bill before Congress. He invoked, among other arguments, "the philanthropic sentiment of Cicero," "the sacredness of contracts," "the obligations of

85. For more detail, see Mezey, "Erasure and Recognition."

86. U.S. Census Office, The Statistics of the Population of the United States ... From the Original Returns of the Ninth Census (Washington, DC: Government Printing Office, 1872), xii.

87. U.S. House of Representatives, 41st Cong., 2nd Sess., Report of the Ninth Census (Washington, DC: Government Printing Office, $1870), 51$ law," "the higher religion we profess," distaste for "sentiments not only so abhorrent to humanity but violative of principles our fathers came here to plant and their sons lived to cherish," and simple "justice." 88

But despite Kennedy's eloquence and his party's early support, the open borders that applied to the rest of the world were not available to many Asian nationalities by the 1870 s. Policy choices ranged only from carefully controlled quotas and guest worker programs to complete exclusion. ${ }^{89}$ After all, so the claim went, the Chinese were categorically different from even the lowliest European immigrants. They were not in all ways inferior-a central charge, repeated ad nauseum, was that they worked too hard for too little pay-but they were "an indigestible mass in the community" who "do not desire to become citizens of this country, and have no knowledge or appreciation for our institutions." 90 The Democratic party was especially hostile to Chinese immigration, and the ideology behind the Chinese question became inextricably bound up with partisan politics. ${ }^{91}$

Antagonism toward the Chinese in particular provides a clue as to why the census began to distinguish Asian nationalities (after which point, path dependency, or bureaucratic stickiness, presumably takes over as an explanation). Many political actors before the turn of the century argued for Chinese exclusion on the grounds that the Chinese were radically different from the Japanese. A California Senate committee reported testimony in 1877 that "it is generally supposed that they [Chinese and Japanese] are the same race; but this is not so. They are of absolutely different origin, and there is no sympathy, no similarity between them....[T]he Japanese are of Turkish blood; of the same race as the Turks or Arabians."92

88. Joseph Kennedy, Argument Adverse to the Bills 409 and 477: U.S. Senate, 45th Cong., 2d sess. (Washington, DC: Government Printing Office, 1878), 2.

89. Moreover, due to treaty obligations, any policy choice would need to be negotiated with the Chinese (and later Japanese) governments. The fact that foreign sovereign powers continued to claim responsibility for their citizens residing in the United States arguably enhanced Americans' perception of Asian immigrants as foreign subjects, not assimilable new Americans.

90. U.S. Senate, 44th Cong., 2nd sess. Report of the Joint Special Committee to Investigate Chinese Immigration (Washington, DC: Government Printing Office, 1877), v, vii.

91. On Chinese exclusion see, among other works, Andrew Gyory, Closing the Gate: Race, Politics, and the Chinese Exclusion Act (Chapel Hill, NC: University of North Carolina Press, 1998); Daniel Tichenor, Dividing Lines: The Politics of Immigration Control in America (Princeton, NJ: Princeton University Press, 2002); Aristide Zolberg, A Nation by Design (Cambridge, MA: Harvard University Press, 2006); Erika Lee, At America's Gates: Chinese Immigration during the Exclusion Era, 1882-1943 (Chapel Hill: University of North Carolina Press, 2007).

92. U.S. House of Representatives, 45th Cong., 1st sess. Chinese Immigration: An Address to the People of the United States upon the Social, Moral, and Political Effect of Chinese Immigration (Washington, DC: Government Printing Office, 1877), 8. 
Others agreed that "some similarities of race exist between ... [Koreans] and Japanese, while the Chinese are quite singular and unlike." ${ }^{.93}$ After all, unlike the despised Chinese, the Japanese were Christian, democratic, cultivated, honest, intelligent, polished, gentlemen, "peaceable, quiet citizens," the "Frenchmen of the east." Japanese were, in short, assimilable; "those we have here now conform to our customs. They have become Americanized. ${ }^{95}$

Not surprisingly, then, in 1890 the census distinguished Japanese from Chinese. Treating Chinese and Japanese as separate groups and separating both from mainstream whiteness reflected and reified the racial order emerging in the earlier Congressional debates. On the one hand, the Japanese, in the minds of some at least, had significantly higher status than the Chinese-even approaching whites (or at least Frenchmen). On the other hand, both nationalities remained unambiguously nonwhite and non-American. Thus both remained legally on the margins of American society, excluded from the mainstream by laws prohibiting naturalization, interracial marriage, certain forms of property ownership, and inheritance. ${ }^{96}$

Taxonomic confusion over what counts as a race, as well as the ideological implications of enumerating distinct Asian nationalities, sat poorly with some census officials. The 1906 Supplementary Analysis on race noted "little scientific ground for attempting to discriminate between the Chinese and the Japanese as of different races. They regard themselves and are regarded by ethnologists as closely related branches of the great Mongolian, or yellow, race. ${ }^{, 97}$ (Unlike other census analyses, this volume did in fact combine the two groups into a single Mongolian category.) Furthermore, the distinction by nationality introduced errors into enumeration; as a census superintendent observed when the number of Asian nationalities had climbed to six, "sometimes it is difficult to decide the nationality even after a personal inspection.... We are certainly trying to gather too much information through the general enumeration. ... We should certainly be justified in confining the questions [about "the foreign element of the population"] to the birthplace and

93. U.S. Congress, 44th Cong, 2nd Sess. Report of the Joint Special Committee to Investigate Chinese Immigration (Washington, DC: Government Printing Office, 1877), 1238.

94. U.S. House of Representatives, 51st Cong., 2nd Sess. Chinese Immigration (Washington, DC: Government Printing Office, 1891), 68, 118.

95. Ibid., 153. A few speakers or officials conceded that if the number of Japanese immigrants began to approach that of the Chinese, they might well change their views (e.g. ibid., 342). But everyone preferred to postpone that issue for the future-when it did, in fact, arise, with the predictable outcome of exclusion.

96. Ronald Takaki, Strangers from a Different Shore: A History of Asian Americans (Boston, MA: Little Brown, 1989).

97. U.S. Bureau of the Census, Special Reports: Supplementary Analysis and Derivative Tables: Twelfth Census of the United States, 1900 (Washington, DC: Government Printing Office, 1906), 176. mother tongue of the person reported. ${ }^{98}$ The drive for simplification and consistency in the definition of a race, however, made no headway.

The question of what is a race became even more confused in the case of South Asians, identified as "Hindus" or "Hindoos" (although the majority were, in fact, Sikhs) ${ }^{99}$ After a first mention in 1880 , they next appeared in 1910, when tables in the Population report identified Hindus, Koreans, Filipinos and a grand total of eight Maoris along with the Chinese and Japanese on the population schedule. ${ }^{100} \mathrm{We}$ have found no official explanation for the religious term Hindu as the racial classification for a linguistically and religiously diverse group of immigrants. ${ }^{101}$ The Census Bureau did, however, spell out the politically expedient and decidedly non-scientific reason for enumerating Hindus as a type of Asian:

\begin{abstract}
Pure-blood Hindus belong ethnically to the Caucasian or white race and in several instances have been officially declared to be white by the United States courts in naturalization proceedings. In the United States, however, the popular conception of the term "white" is doubtless largely determined by the fact that the whites in this country are almost exclusively Caucasians of European origin and in view of the fact that the Hindus, whether pure-blood or not, represent a civilization distinctly different from that of Europe, it was thought proper to classify them with nonwhite Asiatics. ${ }^{102}$
\end{abstract}

As "distinctly different" cultural outsiders, South Asians were too foreign to warrant status as whites or as possible insiders, regardless of their bloodlines. Within a decade the Supreme Court's decision in United States $v$. Thind echoed the Census Bureau, and South Asians were formally banned from naturalizing as American citizens. Science in this instance could have served as a counter to ideology, and could have turned a low-status, excluded group into

98. William Steuart, "The Conduct of the Fourteenth Census," Quarterly Publications of the American Statistical Association 17 (1921): 575 .

99. Karen Leonard, Making Ethnic Choices: California's Punjabi-Mexican-Americans (Philadelphia: Temple University Press, 1992); H. Brett Melendy, Asians in America: Filipinos, Koreans, and East Indians (Boston: Twayne Publishers, 1977).

100. U.S. Bureau of the Census, Population 1910: Volume 1, General Report and Analysis (Washington, DC: Government Printing Office, 1913), 129

101. The term "Hindu" may have derived from popular terminology for language ("Hindustani") or geographic location ("Hindustan"), but it is not clear why this term was chosen instead of other possibilities. Confusion was the dominant feature: for example, enumerators recorded incorrect language for Punjabi immigrants (Leonard, Making Ethnic Choices), and Muslim immigrants from South Asia were assigned a wide variety of mother tongues and countries of birth (Vivek Bald, "Overlapping Diasporas, Multiracial Lives: South Asian Muslims in U.S. Communities of Color, 1880-1950," Souls 8 [2006]: 3-18).

102. U.S. Bureau of the Census, Population 1910, 126. 
a higher-status, included one by redefining its race. It proved, however, too weak a force in this intensely ideological environment.

Enumeration and Identity Cards: We found, in fact, only one occasion in which the attempt to make the census a tool of Asian exclusionary ideology failed. In 1890 a bill that would have required the Census Office to issue an identification card to each enumerated Chinese person passed in the House of Representatives but failed in the Senate. The card would be the only proof of legal residency; "any Chinese person found in the United States without such certificate shall be deemed to be unlawfully in the United States, and may be deported therefrom." ${ }^{103}$ The bill's sponsors were concerned that despite the Chinese Exclusion Act, "such immigration continues to come into the United States clandestinely over the border from Canada and Mexico, and promises to continue unless effective measures are taken ... to distinguish those who shall hereafter unlawfully come into the United States." "I04 In short, the census was to be the vehicle for identifying those who are now called illegal aliens.

Proponents argued that "it is undoubtedly the purpose of this bill to segregate these people by this enumeration, which shall describe and define and limit them, so that subsequent accessions to this population shall be prevented." ${ }^{105}$ Census data could and should serve ideological and partisan purposes. Opponents, however, objected that the bill contains "some provisions of a penal character ... that does [sic] not belong in a census enumeration. A census enumeration is to learn who the people are, who are here." ${ }^{106}$ Sen. James Eustis (D-LA) was the most eloquent:

It strikes me as a little strange that the Census Committee, which is a committee charged, as I understand, with simply the duty of having the population of this country enumerated... should undertake to report to the Senate a bill which has nothing to do with the question of census, but has a great deal to do with the question of not only municipal police, but of international-law relations and obligations.... Why, in the absence of any provocation whatsoever, should we provide in taking a census that this people shall wear a tag like animals? ${ }^{107}$

103. U.S. House of Representatives, 51st Cong., 1st Sess. Enumeration of the Chinese Population of the United States (Washington, DC: Government Printing Office, 1890), 1.

104. Ibid.

105. U.S. Senate, 51st Cong., 1st Sess. Congressional RecordSenate (Washington, DC: Government Printing Office, 1890), 2979. 106. Ibid., 2982.

107. If only to show that partisan politics is never far from ideology, the Democratic Senator Eustis went on to deplore the need, if this bill passed, "to have hundreds of additional Republican enumerators.... If they want to increase the expenditures for this census and to increase their vast army of enumerators, it can be done without presenting to the Chinese residents of our country
Senator Eustis assured his colleagues that "you have a race prejudice against these Chinese. So have I. I avow it. ... [T] here is such a thing as antagonism of races." Nevertheless, "if we are to reopen this question of Chinese exclusion, let it be done in a proper way and not under disguise and concealment, under the sham and mockery of taking a census."108

The bill failed in the Senate through an alliance among those who thought it too weak because it left loopholes for determined Chinese to sneak through, the few opponents of Chinese exclusion, and those who objected to using the census for punitive purposes. We found no record of census officials' views (although one senator reported that the superintendent favored it). To our knowledge, no one tried again to make the census such an explicit instrument of surveillance and control until it was used to aid Japanese internment in World War II. In the case of Chinese identity tags, although not in the case of the classification system overall, a commitment to insulate the census and treat it as a neutral scientific endeavor won out, just barely, over ideology and politics.

With this exception, counting Chinese (and later, other Asian) immigrants was indeed "a mechanism for imposing order and racial clarity on the proliferation of an ambiguous alien." 109 Two features of this mechanism remained in place to shape the racial order with regard to Asians throughout the twentieth century. First, order or clarity never did emerge. The number of Asian nationalities on census schedules rose, and later fell; state enumerations used different categories from national ones; and territorial enumerations (including Hawaii and the Philippines) were never integrated into the national system. The (incorrect) Hindu religious designation appeared, remained for some decades, and then disappeared. Second, Asians' place in the American racial order was uniquely rooted in nationality. To put it more pointedly, nationality was consistently racialized in the case of Asians. And despite the fact that the Census Bureau and some elected officials realized that social scientists use "Asian" as a racial category analogous to "black" and "white," a combination of ideological exclusivity, international pressures from various Asian governments, and bureaucratic stickiness led to the perpetuation of nationality as the designator for Asian Americans' place in the United States' racial order. Taxonomically speaking, an element of perennial foreignness has remained even as Asian Americans' status in the vertical racial hierarchy has risen.

chromos and engravings. A leather tag would be much cheaper. I have no doubt that you could buy one for 10 cents and tie it to a string and let a Chinaman wear it around his neck" (ibid., 2980). 108. Ibid.

109. Mezey, "Erasure and Recognition," 1730. 


\section{WHITENESS: RACE, STOCK, PEOPLES, AND MIXED PARENTAGE}

\begin{abstract}
"If we were receiving immigrants from the north of Italy," he said, "it would be an entirely different matter, but all the Italians who are coming in now are coming from the 'toe' and the 'heel' of Italy, and from Sicily. You see, the north of Italy are really Celts like the French and Irish, being descended from the Lombards, but the Sicilians and Calabrians are a mixture of the old pirates, the Moors, and the degenerated Latin races that were left when the Roman Empire fell to pieces."
\end{abstract}

The issue of immigration regained urgency as the foreign-born population from southern and eastern Europe soared around the turn of the twentieth century. How many should be admitted to the United States, and from where? Where should they be put in the racial order? Should they be included at the top of the hierarchy because they could be defined as white, or in some mid-range because they were neither black nor Anglo-Saxon? Could they be treated as potential insiders in the American mainstream, or were they too perennial outsiders who could never be fully incorporated? Political actors turned to census data to find categories for making sense of the new European immigrants and for information that would help to determine how the racial order should once again be reorganized.

Providing the Language to Debate the Sources of Social Turmoil: Every branch of the federal government and many state and local governments became embroiled in ideological debates around immigration-as did the Census Office. Census officials were in the front ranks of nativists. To choose only one example, Francis Walker, the powerful superintendent of the 1870 and 1880 censuses, later described southern and eastern Europeans in Darwinian language; they were "beaten men from beaten races; representing the worst failures in the struggle for existence." ${ }^{111}$ In contrast to the welcome for earlier immigrants "descended from the tribes that met under the oak-trees of old Germany to make laws and choose chieftains," the "patriotic American of to-day may properly shrink in terror from the contemplation of the vast hordes of ignorant and brutalized peasantry thronging to our shores." 112 He used census data (partly from censuses that he had overseen) to argue that the native-born white population was shrinking because Americans were reluctant to bring children into a world in which they must

110. Rolt-Wheeler, The Boy with the U.S. Census, 202.

111. Francis Walker, Discussions in Economics and Statistics, vol. 2: Statistics, National Growth, and Social Economics (New York: Henry Holt and Company, 1899), 447.

112. Ibid., 439 engage in unfair competition with undesirable immigrants. ${ }^{113}$

A few people associated with the census rejected such xenophobia. As we discussed above, former Superintendent Kennedy challenged Congress's proposal to exclude the Chinese by observing (inaccurately [see note 62]) that "I do not have pleasure, while considering a question of morals or policy, in calling attention to the difference in nationality, color, or creed, and in the forty-three years I have written on public questions have never done so." He nevertheless observed sarcastically that "the great influx of foreigners at another period from all portions of Europe ... led to alarm for the safety of American institutions, and some of us are old enough to recollect that the same political use was then made of fancied dangers to the entire country which is now being indulged on the Pacific coast." ${ }^{114}$ His message: alarm over the "wrong" kind of immigrants was unnecessary then, and is no more warranted now.

Ideological contestation was made concrete through political disputes over census categories and instructions; classification "provided, if you will, the language to debate the sources of the social turmoil." ${ }^{115}$ By 1880 , questions about nativity took up a quarter of the space on the population schedule. In subsequent decades, detailed analyses of new immigrants' settlement patterns and characteristics replaced detailed analyses of black migration in the population reports. One incident reveals the complex dynamics: after intense lobbying and logrolling, including a conference of all interested parties called by the census director, Congress required queries about "mother tongue" (for the foreign-born and their parents) only one month before enumeration was to start in 1910. Some years later, census director E. Dana Durand captured the mixed motivations behind the appearance of mother tongueas well as the decided ambivalence of the person called on to implement what we would now call an extensive unfunded mandate:

It was recommended by the Director of the Census [his predecessor], partly on account of the scientific value of the information, but more because of the insistent demand of the leading representatives of the races coming from Austria-Hungary. There is no question that the information would be of much scientific value if it could be obtained with accuracy and without unduly burdening the enumerator. Save with respect to a few countries, however, ... the additional information secured by the

113. Ibid., 417-26; for a refutation, also using census data, see J. M. Gillette, "Immigration and the Increase of Population in the United States," Social Forces 5 (1926): 37-51.

114. Kennedy, Argument Adverse, 7, 12.

115. Anderson, The American Census, 133. 
mother-tongue inquiry is not worth the trouble and expense it causes. ${ }^{116}$

Nevertheless, as the next sentence reported with an air of resignation, "The instructions to enumerators for 1920 contain a list of 63 principal languages, and the enumerators are expected to report many others."117 Obtaining information to help in deciding what to do about the huge influx of immigrants was too urgent a matter for the federal and state governments for the small problem of feasibility in implementing new categorizations to stand in the way.

Who and What Is White? From today's vantage point, one's main impression of changing census classification schemes with regard to whites is that the distinct motivations of ideology, partisanship, and science simply got swamped by the struggle to understand the bewildering array of newcomers. The old racial order among what we now describe as whites unraveled by 1910 and it took decades and many false starts to construct a new one. Even setting aside large ideological debates about assimilation, exclusion, and racial hierarchy, questions about categorization were legion: What are the conceptual and empirical links among country of birth, race, color, nationality, class, mother tongue, blood, stock, and peoples? How should distinctive groups be aggregated, and how should aggregated groups be distinguished? Where is the line between native- and foreign-born, and how do populations on both sides or in the middle differ from one another? How should one categorize those born at sea or with parents born at sea, or those born in a nation or empire that no longer existed?

Congress and the Census Office (later, Bureau) experimented continuously with answers to such questions. In 1870 and 1880, enumerators were instructed to provide states instead of Germany ("as Prussia, Baden" etc.); in 1900, however, they were told, "Do not write Prussia or Saxony, but Germany."118 In 1890 and 1900, enumerators were instructed to identify "English" or "French" for people born "in Canada or Newfoundland;" this instruction appeared in no other years, despite the claim that "this is a most important requirement, and must be closely observed in each case and the distinctions carefully made. ${ }^{119}$ In 1890, enumerators' instructions also included the sentence, "In case the person speaks Polish, as Poland is not now a country, inquire whether the birthplace was what is now known as German Poland or Austrian Poland or Russian Poland and enter the answer accordingly as Poland (Ger.), Poland (Aust.), or Poland

116. Memo by Durand, quoted in Steuart, "The Conduct of the Fourteenth Census," 574.

117. Ibid., 575 .

118. U.S. Bureau of the Census, Measuring America, 15, 37.

119. Ibid., 28. Emphasis in original.
(Russ.)." ${ }^{120}$ Instructions for categorizing immigrants occupied a growing number of dense pages as the bureau struggled to capture with precision the political vagaries that produced languages in 1910 such as Wendish, Lettish, and "Rhaeto-Romanish (including Ladin and Frilulan)," or nationalities such as "Turkey in Europe" versus "Turkey in Asia."

Basic terminology was no more fixed than were nationality labels. Referring to the decade after 1840, Walker wrote that "for the first time in our history, the people of the free States became divided into classes. Those classes were natives and foreigners." 121 The 1906 Supplementary Analysis on race noted that the word "race" was "used in popular speech with much looseness," and admitted that the term was even defined differently across the 1900 census publications. ${ }^{122}$ In 1914 the census director assayed a different use of the same term; he described a forthcoming special report on "racial classes of population," which did not include Indians and Negros; the racial classes were distinguished by country of origin but were all contained within the "white population of foreign stock."123 The Senate inserted "race" (meaning roughly European ethnicity) into the 1910 census, but the conference committee between House and Senate deleted it. ${ }^{124}$ The census director explained to a Senate committee a few months later that "race' in its broadest sense" should be understood as "five classifications, white, black, Chinese, Japanese, and Indians"but another expert witness reported that a person born in Austria of Polish origin "is German or some other race - a Pole or a Bohemian" on the census. $^{125}$

One cannot be surprised at the classification muddle when one considers what material the Census Bureau had to work with. ${ }^{126}$ Senate hearings in 1909 on the upcoming census give a flavor of the efforts to make sense of these new groups:

Senator Carter: How do you distinguish between nationality [and] race in your classification? What do you mean by the word race?

Mr. Husband [Immigration Commission Secretary]: It is not the racial classification by color that is commonly known but a

120. Ibid., 37.

121. Walker, Discussions in Economics and Statistics, 424

122. U.S. Bureau of the Census, Special Reports, 176.

123. U.S. Bureau of the Census, Circular of Information Concerning Tentative Program of the Bureau of the Census. (Washington, DC, Department of Commerce, Bureau of the Census, 1914), 2, 5.

124. Perlmann, 'Race or People"

125. Qtd. in Ibid.

126. Senator Dillingham's Immigration Commission is outside the purview of this article, but it of course contributed the famous and then-authoritative Dictionary of Races or Peoples to the mix (U.S. Immigration Commission, Dictionary of Races or Peoples [Detroit, MI: Gale Research Co., 1969, orig. 1911]). 
race classification which was agreed upon ... at least, I understand someone connected with the Smithsonian Institution worked out the classification of races.

Senator Carter. You refer to the Poles as a race; they are not a race at all. As I understand the word "race," it is a nationality. Would you refer to the Irish as a race? They are not a race; they are part of a race.

And a little later:

Senator Carter: I imagine that in taking the census they would find extreme difficulty in the refinements of the races to which your remarks refer, Senator Guggenheim. The Chairman [Senator LaFollette]: Suppose it were limited to immigrants? I can see there would be extreme difficulty if that question is asked of everybody. It would be a question of where the racial lines should be drawn. Conditions are such that a great many people could not really state where they belonged, but if you limited it strictly to immigrants, that difficulty might be avoided.... I can see broad ethnological reasons why some time it would be important to know from what blood and race the man came.

The issue of self-chosen identity versus external identification also played a role in these deliberations:

Senator Cummins: Do you claim the Spanish and Italian people as of different races?

Mr. Husband: Yes ...

Senator Guggenheim: Suppose they were Jews who came from Spain, would they be classified as Jews or Spaniards?

Mr. Husband: That would depend a good deal on what the man claimed to be.

Senator Guggenheim: I do not think that has anything to do with it. It is purely a question of what is right. ${ }^{127}$

They never did sort it out.

By 1930, the classificatory chaos had settled down, and the underlying ideology of white supremacy had been reasserted. Notions of whiteness were consolidated: the Census Bureau still enumerated and provided information on people of mixed parentage (foreign and native born), but instructions to enumerators were much less clotted.

In retrospect, it seems obvious that the speakers of Lettish and Wendish, the Yiddish-speaking Jews who demanded classification by mother tongue so that

127. Qtd. in Perlmann, Race or People. they could be separated from their Austro-Hungarian rulers, the Poles whose nation had disappeared, those of mixed parentage or who were unclassifiable because their parents were born at sea-all would eventually be folded into the category of assimilable "white," insiders ranking high on the racial hierarchy. That outcome probably also seemed clear to at least some of the actors at the time; the census director's five classifications of "race in its broadest sense" did not, after all, include any European nationalities. But we need to take care not to predict backwards. One can find statements by influential senators and public leaders in the 1910s and 1920 s as virulently hostile to new European immigrants as any thrown at Chinese, Japanese, or Negroes a few decades earlier. ${ }^{128}$ And the thriving eugenics movement aimed at least as much at undesirable European immigrants as at already-subordinated blacks or largely-excluded Asians. ${ }^{129}$ Fully incorporating European immigrants into the status of white in the American racial order required many years, might have failed had immigration continued at high levels, and might not have occurred had census classifications developed in different directions.

\section{HALF-BREEDS AND FULL-BLOODED INDIANS}

Whether Indians would be required to remain on the outside edge, or could be included as insiders in the American polity, even if of low status, was contested from the time that Europeans first set foot on what they labeled "America." The Constitution's call for a decennial census specified inclusion of "all Indians taxed" and exclusion of "Indians not taxed." This distinction shaped Census Office decisions about enumerating Native Americans from 1790 onward.

The Social Construction of an Indian: The legal term "taxed Indians" came to mean those of Native American descent living among whites. Although they were first classified as white, in 1860 the Census Office instructed enumerators to identify them separately as Indian. From that point on, the classification system for Indians living in mainstream society remained stable and unproblematic, even though the actual counts were highly inaccurate for decades. ${ }^{130}$ Census documents barely mentioned

128. Matthew Jacobson, Whiteness of a Different Color: European Immigrants and the Alchemy of Race (Cambridge, MA: Harvard University Press, 1998); King, Making Americans; Madison Grant, The Passing of the Great Race; or, The Racial Basis of European History (New York: C. Scribner, 1916).

129. John Haller, Outcasts from Evolution: Scientific Attitudes of Racial Inferiority, 1859-1900 (Carbondale: Southern Illinois University Press, 1995); Edward Larson, Sex, Race, and Science: Eugenics in the Deep South (Baltimore, MD: Johns Hopkins University Press, 1996); Daniel Kevles, In the Name of Eugenics: Genetics and the Uses of Human Heredity. (Cambridge, MA: Harvard University Press, 1995).

130. Seltzer and Anderson, Excluding Indians Not Taxed. As one census historian put it, "One does not have to be an expert to sense 
these Indians, often incorporating their numbers into other small racial groups like the Chinese and Japanese under the heading "Minor Races."

The question remained, however, of how to racially categorize taxed Indians with both Native and nonNative ancestry. The Census Office resolved it in a surprisingly pragmatic manner. Superintendent Walker rejected in 1870 any "analogy... relating to the former slave population of the country. The rule that the child should follow the condition of the mother was the bad necessity of a bad cause, which required every point to be construed against freedom. Something very nearly opposed to this would seem to be in accordance with the present spirit of our laws, as well as to be the dictate of common sense." Thus he turned to what we now call social construction; "in the equilibrium produced by the equal division of blood, the habits, tastes, and associations of the half-breed are allowed to determine his gravitation to one class or the other." "Persons of part-Indian blood" who lived among whites, "adopting their habits of life and methods of industry" should be counted as white, while the "opposite construction" applied to those "found in communities composed wholly or mainly of Indians."

Walker presented this framework as simple common sense. But underlying it were two profound ideological assumptions. First, Indians were not like negroes. Virtually no one depicted mulattoes as anything other than a type of negro, whereas mixed-race Indians could easily join white society. Thus the hierarchical dimension of the American racial order differed for the two groups-a drop of black blood was a barrier to mainstream incorporation, while a drop of Indian blood was not. ${ }^{132}$ Second, Indians were not like Chinese. Almost everyone depicted the Chinese as perennial foreigners, unwilling and unable to become genuine Americans, whereas if Indians were willing to "adopt [whites'] habits of life" and abandon their claims to sovereignty and to land that white settlers wanted, they were invited to do so. Thus the census both reflected and consolidated the fact that the horizontal dimension of the

that these numbers do not describe real people" (Alterman, Counting People, 293).

131. U.S. Census Office, The Statistics of the Population of the United States (1872), xiii.

132. Public policies reflected this distinction. Every state with at least a 5 percent black population enacted laws banning marriage between blacks and whites (Randall Kennedy, Interracial Intimacies: Sex, Marriage, Identity, and Adoption [New York: Pantheon, 2003], 219), while state laws against Indian-white marriage were comparatively rare (Thomas Ingersoll, To Intermix With Our White Brothers: Indian Mixed Bloods in the United States from Earliest Times to the Indian Removal [Albuquerque: University of New Mexico Press, 2005], 241).
American racial order differed between these two lowstatus groups.

Walker's approach towards racially mixed Indians was by definition irrelevant to Indians untaxedthat is, those living on reservations or in tribes beyond the bounds of white society. The implication of their racial mixture was a far more contentious policy issue. In 1876 the Commissioner for Indian Affairs made the first serious attempt to count the proportion of mixed blood to full-blood Indians. The Census Office followed up with a special census of untaxed Indians in 1880, in which enumerators were told to specify what fraction of each person's "blood" was white or black, and whether white, black, or mulatto persons had been adopted into a tribe. (This enumeration was never completed or published; Congress cut off appropriations to the Census Office after years of waiting for most results of the massive 1880 census. ${ }^{133}$ )

The Dawes Act of 1887 restructured the relationship between the federal government and most tribes, granting American citizenship to full and mixedblooded Indians who "civilized" according to the terms laid out by the state. It also required the government to clearly define the boundary between white and Indian. Thus in 1890 Congress again mandated a special census of Indians untaxed. Despite barriers of mistrust, misunderstanding, and logisticsincluding at least one enumerator's capture by an outraged tribe-the Census Office produced five elegant, informative, and lavishly illustrated books on particular tribes, as well as a massive volume with detailed statistics, state-by-state analyses, and a history of federal policy towards Indians. Included in the array of information were data on the blood quantum of tribal members. (The schedule for the more racially mixed "Five Civilized Tribes" of Oklahoma was especially complex, asking whether each person was white, black, mulatto, quadroon, octoroon, Chinese, Japanese, or Indian, with tribe or clan.) The results were, however, highly unreliable, as a special report angrily noted:

\begin{abstract}
The separation of Indians from the general population in the conditions now prevailing in considerable portions of the country is exceedingly difficult and unsatisfactory. The number of persons east of the Mississippi who would suggest to an enumerator by their appearance that they have any Indian blood is very small. Enumerators would be likely to pass by many who... lived like the adjacent whites without any inquiry as to their race,
\end{abstract}

133. The census's inquiry into Indians' racial mixture coincided with increased attention in other realms of federal policy. The government "continued to discourage racial intermarriage on or near Indian reservations, for the sake of civilizing the Indians, $\ldots$ by encouraging mixed individuals to give up their tribal status and be separated from their tribes" (Ingersoll, To Intermix With Our White Brothers): 243-44. 
entering them as native born whites. On the other hand, certain legal and proprietary claims lead persons of very slight Indian blood connection, or even pure whites by birth, to call themselves Indian by hereditary or acquired right, and there are those of pure white blood who wish to be called Indians, in order to share in pecuniary advantages, who are not acknowledged by any tribes. These Indians for revenue ... constitute a perplexing element to the courts, to the Indian Office, to the Census Officers, and to everyone who attempts to deal accurately with the conditions of Indians. ${ }^{134}$

In an ideological environment ranging from genocidal hostility to despair over the destruction of great civilizations, the drive for scientific precision stumbled over the socially (and instrumentally) constructed realities of race in real life. The effort to collect valid data was further undermined by the huge "pecuniary advantages" at stake which Congress, the Office of Indian Affairs, tribal governments, and state governments all were vying to control. The tensions could not be resolved; the Census Office tried another special census of untaxed Indians in 1900, but once again never published the results.

Boas, Dixon, and Racial Mixture: Just over a decade later, the United States government shifted policy again. It forced Indians with one half or more white blood off the tribal rolls established under the Dawes Act, thus requiring them to forsake tribal land claims and become subject to federal taxes. At the same time, a new generation of scholars was challenging the purported racial science that had previously undergirded policy towards Indians. The census was a battleground for this debate, with a surprising outcome.

In a line of research starting in 1894, anthropologist Franz Boas produced a study that contradicted his many contemporaries' claim that race-mixing produced inferior progeny. In 1899 he called for census data to answer the pressing policy question of whether "it is desirable to promote mixture between the Indians and other races:"

$[\mathrm{W}]$ ith the increase in settlement in our country, the chances for the Indian to survive as an independent race will become slighter and slighter. The opinion is frequently held that half-breeds ... are much inferior in physique, in ability, and in character, to the fullbloods. But no statistical information is available which would justify a conclusion of this character. If there was a decided deterioration of race, due to mixture, it would seem that the opportunity for race mixture should be

134. U.S. Census Office, Report on Indians Taxed and Indians Not Taxed in the United States (except Alaska) (Washington, DC: Government Printing Office, 1894), 131. limited so far as this can be accomplished. On the other hand, if race mixture seems to be advantageous, it should be facilitated, particularly by bringing the Indians into easy contact with the whites. ${ }^{135}$

Nothing came of this call in 1900, but the 1910 special census of Indians was overseen by Roland Dixon, the head of Harvard's anthropology department. Dixon was a self-proclaimed polygenicist, with no desire to endorse his former professor Boas's optimism about race-mixing. ${ }^{136} \mathrm{He}$ was also a scientist, with no patience for social constructivist vagueness, so he provided excruciatingly exact instructions to enumerators:

If the Indian is a full-blood, write "full" in column 36, and leave columns 37 and 38 blank. If the Indian is of mixed blood, write in column 36,37 , and 38 the fractions which show the proportions of Indian and other blood, as (column 36, Indian) 3/4, (column 37 , white) $1 / 4$, and (column 38, negro) 0 . For Indians of mixed blood all three columns should be filled, and the sum, in each case, should equal 1 , as $1 / 2,0,1 / 2 ; 3 / 4,1 / 4,0$; $3 / 4,1 / 8,1 / 8$; etc. Wherever possible, the statement that an Indian is of full blood should be verified by inquiry of the older men of the tribe, as an Indian is sometimes of mixed blood without knowing it. ${ }^{137}$

It is hard to imagine that enumerators followed these directions to the letter. Nevertheless, when the data were compiled, in amazing detail, Dixon asserted their accuracy and reported without comment a stunning reversal of contemporary conventional wisdom: "the results of the studies on sterility, on fecundity, and on vitality all point toward one conclusion, and that is that the increase of the mixed-blood Indians is much greater than that of the full-blood Indians." Given Darwinian assumptions about the survival of the fittest, "unless the tendencies now at work undergo a decided change the full-bloods are destined to form a decreasing proportion of the total Indian population and ultimately to disappear altogether." 138

135. Franz Boas, "The Census of the North American Indians," in The Federal Census: Critical Essays by Members of the American Economic Association, ed. American Economic Association, (New York: Macmillan Co., 1899), 51.

136. Katherine Moos, "Race Theory in American Ethnology: Roland Dixon and Alfred Kroeber, 1900-1930" (Senior thesis, Harvard University 1975).

137. U.S. Bureau of the Census, Measuring America, 56.

138. U.S. Bureau of the Census, Indian Population in the United States and Alaska, 1910 (Washington, DC: Government Printing Office, 1915), 35. Dixon was remembered for this contribution to anthropology. His obituary in the journal of the American Philosophical Society praised the 1910 special census as "the most complete and accurate enumeration of the Indian population by stocks and tribes," and called his analysis "probably the most valuable work extant dealing with the vital statistics of racially mixed 
Dixon, in short, accepted the scientific principle of falsifiability, and thereby rejected his prior commitment to polygenesis in the face of census data showing the notion of mixed-race degeneracy to be flat wrong. His is the most dramatic, though not the only, example of census officials' efforts to distinguish scientific inquiry from the intense political and ideological whirlwinds swirling around and through them.

By the 1930 census, officials accepted that categorization as an Indian or part-Indian could not reach Dixon's standards of precision. They nevertheless continued inquiry into blood quantum, justifying it along sociological rather than biological grounds: "The sociologist may still be interested in returns which show the proportion of the tribe who consider themselves or who are considered by the social group as full-blood Indians." 139 To a degree, subsequent legislation confirmed this sociological framing: the Indian Reorganization Act of 1934, which redefined the relationship between tribes and the federal government, also reversed who was to be considered Indian. It now included all members of recognized tribes regardless of blood quantum, as well as anyone living off of a reservation who could claim more than half Indian ancestry. With that Act, disputes about the location of Indians in the American racial order shifted away from concerns about whether individuals could become insiders and rise in status, to the legal and financial relationship between tribes and the state or federal governments. The role of the census in defining this element of the racial order largely disappeared.

\section{THE MEXICAN RACE}

During the nineteenth century, the Census Office did not consider the people we now call Latinos or Hispanics to be formally distinct from whites. Congress said nothing about their classification and we have found no textual discussion in census documents. Census enumerators did perhaps make attempts of their own to distinguish them from whites; western states, especially Colorado, were reported in 1880 to have an unusually high number of mulattoes despite very small black populations. Many of the so-called mulattoes had Spanish surnames. ${ }^{140}$

However, classification of Mexican Americans became sharply salient in 1930. The Census Bureau

marriages" (Earnest Hooton, "Roland Burrage Dixon," Proceedings of the American Philosophical Society 75 [1935]: 772).

139. U.S. Bureau of the Census, Indian Population 1930 (Washington, DC: Government Printing Office, 1937), 1, 70.

140. Brian Gratton and Myron Gutman, "Hispanics in the United States, 1850-1990: Estimates of Population Size and National Origin," Historical Methods 33 (2000): 137-53; and Schor, "Mobilising for Pure Prestige?" provides similar data for 1910 and 1920. added "Mexican" to the list of choices in the "Color or race" inquiry, telling its enumerators that "practically all Mexican laborers are of a racial mixture difficult to classify, though usually well recognized in the localities where they are found. In order to obtain separate figures for this racial group, it has been decided that all persons born in Mexico, or having parents born in Mexico, who are definitely not white, Negro, Indian, Chinese, or Japanese, should be returned as Mexican."

That is not an instruction that would satisfy a statistician. Enumerators were not told what to do if the person was part Negro (or Indian, white, or Asian) and part Mexican, or if only one parent was born in Mexico, or if people in the locality disagreed with one another or the person being counted. The bureau paid no attention to grandparents, even though by then state legislatures and courts were considering third, fourth, and even fifth generation ancestry in order to determine who was a Negro. The instruction was vague about whether enumeration as Mexican should be determined by class and if so, how the class was to be defined (it specified "laborers" in the first sentence but "persons" in the second). Most importantly, the bureau ignored the fact that the United States had by that point decades of experience and dozens of court cases showing the impossibility of deciding who is "definitely not" white, Negro, Asian, or Indian.

A scientific desire for demographic precision, therefore, is not a good explanation for the sudden appearance of Mexican as a racial category on the census. Instead, the Census Bureau was responding to political pressure. By the end of the 1920s, nativists were turning their attention from the now-mostlyexcluded European immigrants to the increasing population of Mexican residents and migrants. The 1930 Population volume acknowledged the pressure delicately: "The Mexican element in the population has increased very rapidly in certain parts of the United States during the past 10 years. By reason of its growing importance, it was given a separate classification in the census returns for 1930, having been included for the most part with the white population at prior censuses." 141

Members of Congress were blunter:

Mr. Johnson: The difficulty in enumerating Mexicans is to enumerate the Americans born of Mexican ancestors...

141. U.S. Bureau of the Census, Population, Volume II: General Report, Statistics by Subjects (Washington, DC: Government Printing Office, 1933), 27. For discussions of closing the "front door" of European immigration while leaving open the "back door" of Mexican migration, see Zolberg, A Nation by Design; Mae Ngai, Impossible Subjects: Illegal Aliens and the Making of Modern America (Princeton, NJ: Princeton University Press, 2005); David Montejano, Anglos and Mexicans in the Making of Texas, 1836-1986 (Austin: University of Texas Press, 1987). 
The Chairman: My inquiry was similar to Mr. Johnson's, in regard to what you [the census director] did with those Mexicans who came over in swarms. ${ }^{142}$

Congress had recently relinquished direct control over the census questionnaire. But members' views on this point were clear, and of course Congress retained the purse strings. It is reasonable to assume that the appearance of Mexican on the 1930 census had more to do with the bureau's political antennae and the nation's increasing hostility to Mexicans in the face of a deepening depression than it had to do with the drive for scientific accuracy.

Having accepted the category, census officials sought to convince people that a separate count of Mexicans could be a source of pride rather than a means of surveillance. The deputy director, for example, wrote to a Texas lawyer requesting articles in local Spanish-language media to promote the upcoming census. He argued that

\begin{abstract}
if the Mexicans in this country could be convinced of the value of the census work and of the impossibility of the information they give being used against them, I believe we could secure their hearty cooperation. The census will furnish most valuable material regarding the number, growth, and economic advancement of the Mexican population in the USA. This is the first census in which Mexicans will be given a separate classification. ${ }^{143}$
\end{abstract}

Such efforts were largely in vain; that Texas lawyer later worked through LULAC (the League of United Latin American Citizens) to overturn the 1930 Mexican classification. ${ }^{144}$ And scraps of evidence suggest that census officials understood well the ideological controversy behind the new category and its implications for those classed as "Mexican" on both the vertical and horizontal dimensions of the racial order. The census director was cited as holding the "opinion that the wealthier class of Mexican call themselves white, whereas the class of peons will return itself as Mexican." One observer noted that "Mexicans are prejudiced against reporting themselves as something else than white." 145

They were prescient. Soon after the 1930 census, the Mexican consul general in New York and the ambassador in Washington, the Mexican government itself, Mexican Americans, and LULAC all vigorously protested the exclusion from whiteness. ${ }^{146}$ The new

142. U.S. House of Representatives, 70th Cong., 1st Sess. Hearings on A Bill to Provide for the Fifteenth and Subsequent Decennial Censuses, Pts. 1 and 2 (Washington, DC: Government Printing Office, 1928), part. 2, 301.

143. Qtd. in Schor, "Mobilising for Pure Prestige?”, fn. 6.

144. Ibid., 99.

145. Qtd. in Schor, "Changing Racial Categories," 7. census enumeration was one of many classification systems that LULAC found unacceptable because their intent was to "discriminate between the Mexicans themselves and other members of the white race, when in truth and fact we are not only a part and parcel but as well the sum and substance of the white race." More pointedly, "Nothing said we had to be segregated. ... Jim Crow did not apply to us." 147

A lot was at stake here. Even if Jim Crow did not formally apply to Mexicans, segregation was vicious in many communities, and hundreds of thousands of Mexicans, perhaps half of them United States citizens, were being "repatriated" to Mexico. ${ }^{148}$ Furthermore, the 1924 immigration law denied permanent residency to anyone racially ineligible for naturalization-that is, to nonwhites (except for Africans). ${ }^{149}$ Thus the countervailing domestic and international political pressure was strong enough that the Census Bureau retreated from classifying the "Mexican race." In 1936, the census director wrote the memorandum quoted in the first epigraph to this article: "The classification by race or color of individuals, or even entire populations, is not only very difficult, but is a very delicate matter to the United States Government, and our classification must always be in accordance with the policy of the Federal Government." He concluded that henceforth "Mexicans are Whites and must be classified as 'White'. This order does not admit of any further discussion, and must be followed to the letter." 150

Racial ideology, in the form of classifying poor brown-skinned Mexicans as nonwhite and presumptively foreign, brought "Mexican" onto the census. International political pressure took it off. The director's 1936 ruling remained in place, and Mexican Americans remained officially white, even if lower on the social status hierarchy than European Americans. By the time "Mexican" reappeared on the census decades later (as an ethnicity, not a race), the chief concern of community leaders was that too many would identify as white, rather than as Mexican-American.

146. Jacob Siegel and Jeffrey Passel, Coverage of the Hispanic Population of the United States in the 1970 Census: A Methodological Analysis (Washington, DC: U.S. Bureau of the Census, 1979), 7.

147. Qtd. in Benjamin Márquez, LULAC: The Evolution of a Mexican American Political Organization (Austin: University of Texas Press, 1993), 32-33.

148. Cybelle Fox, The Boundaries of Social Citizenship: Race, Immigration and the American Welfare State, 1900-1950 (Ph.D. diss., Harvard University, 2007).

149. Marian Smith, "Other Considerations at Work: The Question of Mexican Eligibility to U.S. Naturalization before 1940," presented at Organization of American Historians, Memphis TN, 3 Apr. 2003; Ngai, Impossible Subjects; Hattam, Ethnic Shadows.

150. Qtd. in Schor, "Mobilising for Pure Prestige?," 99-100. 


\section{DEMOGRAPHIC CHANGE AND TAXONOMIC INSTABILITY}

When through Atlantic and Pacific gateways, Slavic, Italic, and Mongol hordes threaten the persistence of an American America, his [the census taker's] is the task to show the absorption of widely diverse peoples, to chronicle the advances of civilization, or point the perils of illiterate and alien-tongue communities. ${ }^{151}$

As we have noted, the almost-century-long experiments in redefining the racial order through census classifications largely ended after 1930. "Mulatto" disappeared; anyone with any black ancestry was now deemed to be a Negro. The "Mexican race" disappeared. "Mixed parentage" among whites disappeared, and "mother tongue" almost did. Asian nationalities remained in place, but the list stopped growing and even shrank in some years. Fractions of white or black blood among Indians remained on special census schedules for a few more decades, but received little attention.

Why did census experimentation with reorganizing the racial order begin and end when it did? For fifty years before 1850 and sixty years after 1930, the census's racial taxonomy was less unstable; but between those years the meaning of race, boundaries between races, and subdivisions within races changed almost every decade for almost every group. Sometimes the classification of individuals was also changed. We have shown the many proximate causes of that variability, but underlying all of it was one fact-the extraordinary transformation of the American state and its population over this period. Consider the following events. Any one would have been somewhat destabilizing; taken together, they show a profound breadth and depth of alteration in the very meaning of the United States. Together they constituted the demographic upheaval that is reflected in the reorganization of the racial order described above.

As readers know, race-based slavery was coming under increasing attack in 1850 and was abolished before 1870 . The polity, as well as the four million previously-enslaved African Americans, needed to figure out how they would be incorporated into the American state. Emancipation entailed physical migration, political incorporation and then disfranchisement, radical economic disruption and then the simultaneous growth of both a new system of sharecropping and a small black middle class, the slow invention of Jim Crow segregation, a degree of cultural innovation, and the eventual formalization of one-drop-of-blood laws in many states. How to understand and respond to racial mixture was a central element of the debate over terms of incorporation, and the Census Bureau, as we have seen, was the

151. Rolt-Wheeler, The Boy with the U.S. Census, Preface. agency to which people turned for crucial information.

Also starting around 1850 and continuing through the early twentieth century, both the size of the American population and immigration dramatically increased. From 1880 to 1930, between four and eight million new residents arrived in the United States per decade, during an era in which the total American population rose from 50 to 123 million. So the country more than doubled in size-and still immigration reached about 15 percent of the American population for many years in those decades. From 1900 through 1920, almost 40 percent of residents of New York City were foreign-born, and about the same proportion of whites (who comprised virtually all of the population) were children of immigrants. Nor was New York City unique; about three-quarters of the residents of other large cities such as Boston, Chicago, Cleveland, Providence, and Detroit were born outside the United States or were children of foreign-born parents. ${ }^{152}$ The census's increased attention to country of birth, mixed parentage, native tongue, and other features of immigration provided one resource for making sense of this reconfiguration of the nation.

Not only were newcomers pouring into the nation, but also, as we have seen, they were coming from places perceived to be dangerously foreign. Chinese immigrants comprised $10 \%$ of the non-Indian population of California in 1870, and they were followed by workers and migrants from other Asian nations and from ambiguously classified countries such as Afghanistan or Iran. Mexicans increasingly migrated across the southwestern border to work in agriculture, railroad construction, and nascent industries. The apparent threat from Chinese, and later Japanese and other Asians, was ruthlessly dealt with. But the "beaten men from beaten races" of southern and eastern Europe were a larger national issue. In 1850 , most immigrants came from Great Britain, Ireland, and Germany; by 1910, a majority of the rapidly increasing population of immigrants were arriving from the Austro-Hungarian empire, Italy, and Russia. They were white, at least in the sense that they were not black or "Asiatic"-but only marginally and questionably so. Their capacity to work and bear children was undoubted; their ability to become good democratic citizens remained in severe doubt in the eyes of many native-born Americans. As Figure 1

152. Richard Alba and Nancy Denton, "Old and New Landscapes of Diversity: The Residential Patterns of Immigrant Minorities," in Not Just Black and White: Historical and Contemporary Perspectives on Immigration, Race, and Ethnicity in the United States, ed. Nancy Foner and George Fredrickson (New York: Russell Sage Foundation, 2004); Ellen Kraly and Charles Hirschman, "Immigrants, Cities, and Opportunities: Some Historical Insights from Social Demography," in The Immigration Experience in the United States: Policy Implications, ed. Mary Powers and John Macisco, Jr. (New York: Center for Migration Studies, 1994). 


\section{YEAR OF IMMIGRATION}

YEAR OF IMMIGRATION OF THE FOREIGN-BORN WHITE POPULATION, BY COUNTRY OF BIRTH: 1930

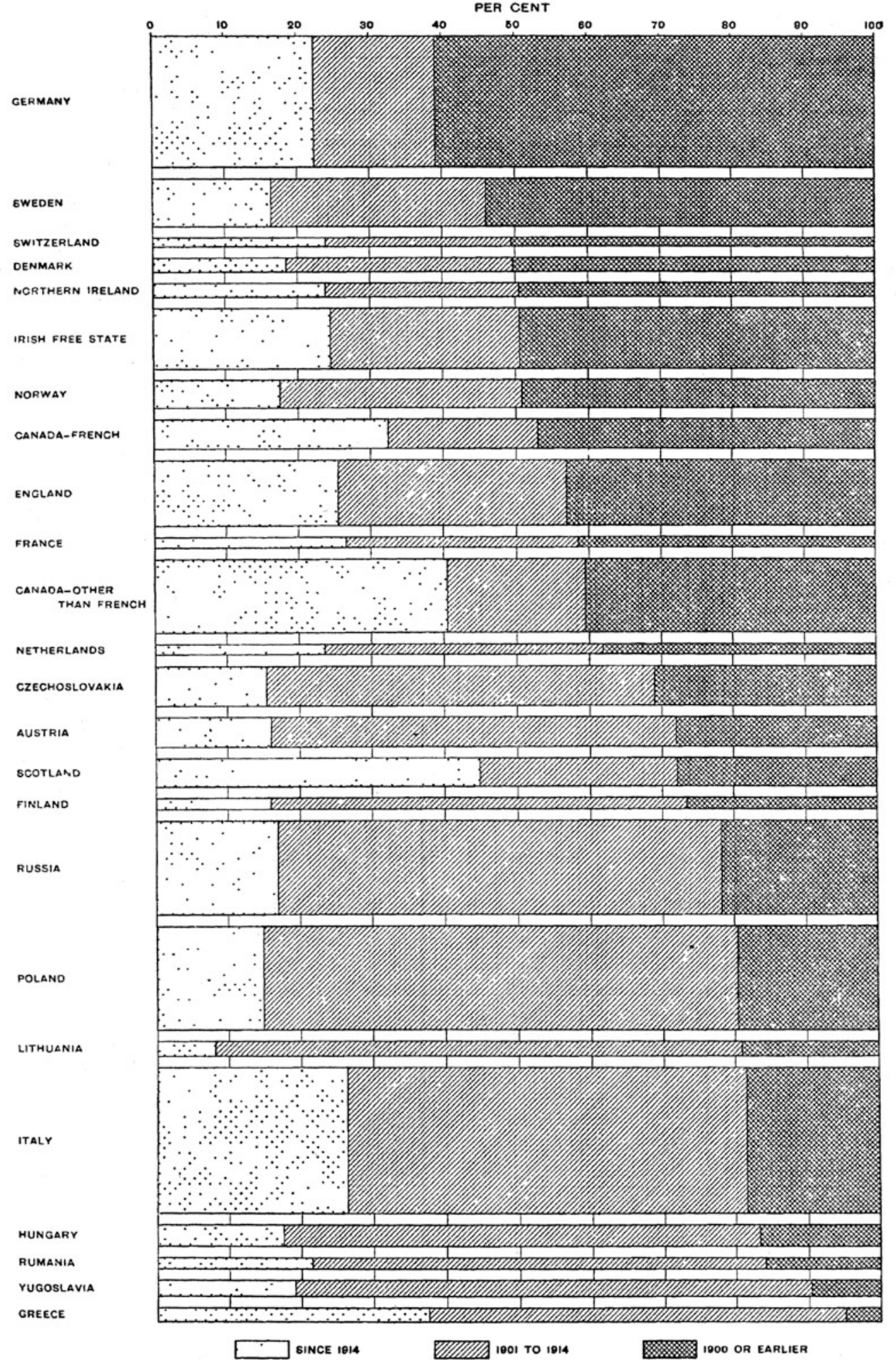

Fig. 1. Year of Immigration of the Foreign Born, by Country of Birth (1930)

Source: U.S. Bureau of the Census, Population, Volume II: General Report, Statistics by Subjects (Washington, DC: Government Printing Office, 1933), 497. 
DISTRIBUTION OF THE POPULATION (FXCLUDING INDIANS NOT TAXED ): 1870

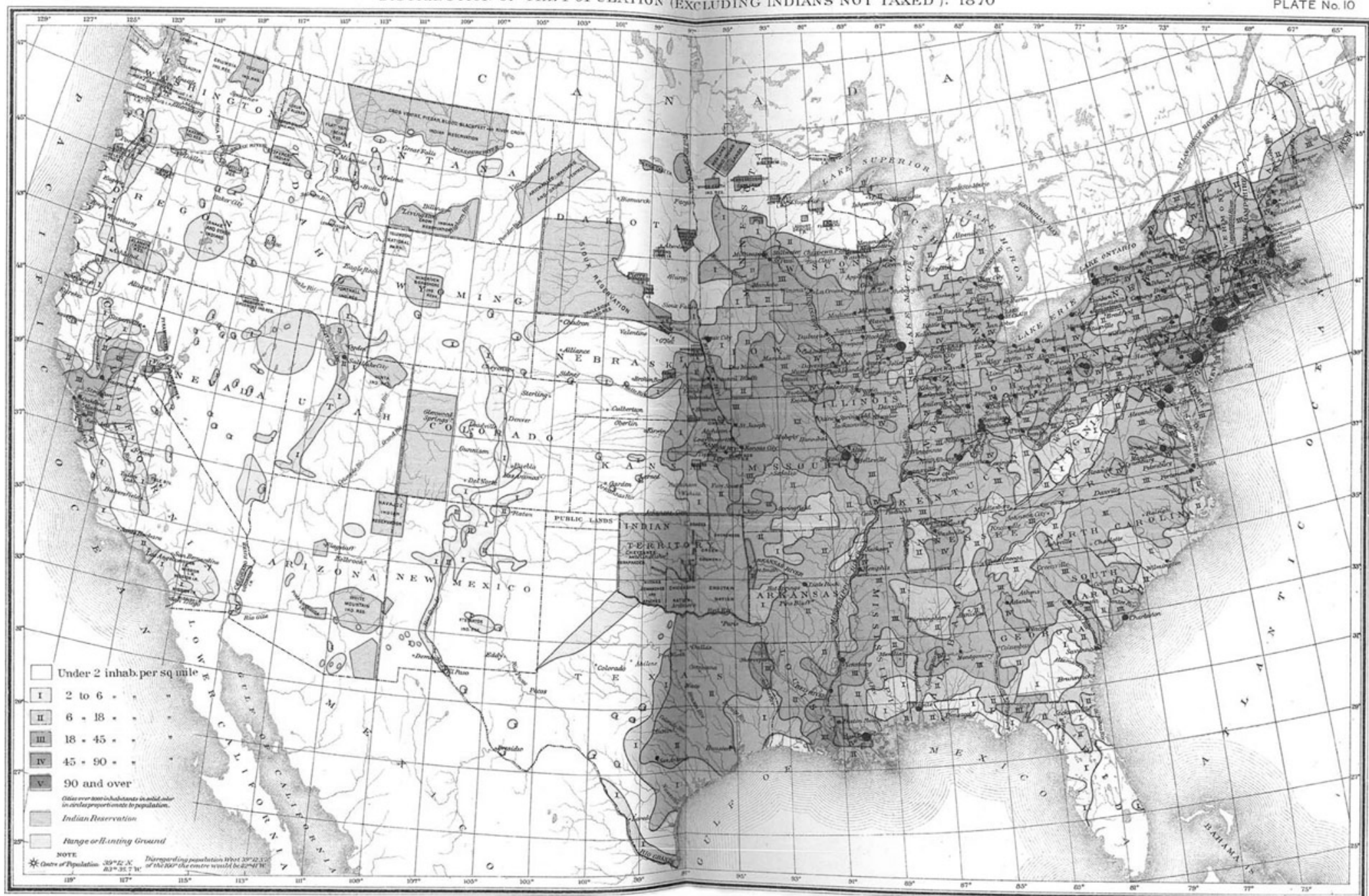

Fig. 2. Distribution of the Population (1870), Excluding Indians Not Taxed

Source: First published in U.S. Census Office, Tenth Census of the United States 1880, Population Volume 1 (Washington, DC: Government Printing Office, 1883), xix. 
shows, the Census Bureau was keeping very careful track of who was migrating to the United States from where in Europe, and at what pace; it developed new forms of statistical analysis and graphical display in order to show this information most clearly.

In the same decades, the United States was engaged in digesting the huge tracts of land it had recently acquired from Mexico, with residents who needed to be incorporated in some fashion into American citizenship. These territories, and other acquisitions in the west and northwest, completely altered the geography and political dynamics of the nation. In 1840, the twenty-six states plus District of Columbia occupied about 910,000 square miles; by 1850, five new states added 580,000 more square miles. Over the next six decades, seventeen more states were admitted to the union, transforming the governance structure and representational systems of the nation and more than doubling the American land mass by adding 1.8 million square miles. ${ }^{153}$ Census maps became increasingly detailed, sophisticated, and attentive to the geography of group density over the last few decades of the nineteenth century, as figure 2 demonstrates.

While huge swaths of land were being acquired and organized into territories and then states, Americans were moving into them at a rapid rate. Between 1870 and 1930, about a quarter of Americans moved from the state in which they were born. ${ }^{154}$ People were also moving from rural areas into cities at a very rapid rate; "intercounty migration rates may have been more than 25 percent higher in the 1850 s than they were from the 1950 s onward." 155 So the Census Bureau needed to deal with very high rates of physical mobility at the same time that the population itself was growing, changing at unprecedented rates, and moving into vast new territory. As Figure 3 shows, the Census Office carefully monitored and graphically displayed westward migration.

Still over the same decades, between 1850 and 1930, treatment of and policies with regard to Indians reversed course several times-from exclusion through forced migration westward, containment on reservations, proposed assimilation (through individual land ownership, schooling away from reservations, and formal grants of citizenship), stripping of reservation lands, and eventually to a commitment to engage with tribes as semi-sovereign though dependent nations. ${ }^{156}$ The population of Indians itself was declining rapidly, due to disease,

153. Authors' calculations from Richard Sutch and Susan Carter, eds. Historical Statistics of the United States: Earliest Times to the Present, Millennial Edition (Cambridge, UK: Cambridge University Press, 2006), table Cf8-64; these figures do not include territories outside the continental United States.

154. Ibid., table Ac1-42.

155. Joseph Ferrie, "Internal Migration," in Historical Statistics of the United States, 1:493. intermarriage, and general maltreatment. In addition to the careful delineation of Indian reservations, as shown in figure 2, the Census Office produced beautiful, detailed, and amazingly informative volumes on Indian tribes, and later on the Indian population as a whole.

Still at the same time, the United States acquired the territories of Alaska, Hawaii, the Philippines, Guam, the Virgin Islands, Puerto Rico, American Samoa, and others. The populations were small but the acquisitions were significant for the Census Bureau because it needed to reconcile census categories and data for each territory with census categories and data from the continental United States (it never entirely managed to do so).

In short, dramatic changes occurred in the size, national origins, and physical mobility of the population; the geographic scale of the nation; the legal status of blacks, Indians, Asians, and other groups; the institutional structure of American governance and the practice of democratic representation; and relations with nationalities or territories outside the boundaries of the state. Many of these changes occurred more than once, moving in differing directions. Readers of this article know all of this, but we believe that scholars of American political development, or at least scholars of the racial order, have taken insufficient account of the magnitude and complex simultaneity of these alterations. The crucial point here is that public officials connected with the census necessarily struggled mightily to ride this wave of transformation, endeavoring to control it through new taxonomies, more complete enumeration, and more sophisticated analyses. We should not be surprised that the Census Bureau failed for almost a century to articulate a stable racial order; what is surprising is that the whole system of census-taking did not simply disintegrate under the impact of centrifugal forces.

It is exceedingly difficult in retrospect to get a sense of how much demographic and political transformation occurred during these ninety years. To help us do so, consider the following thought experiment: Imagine that in the period from 1950 through 2030, the following events all transpired or will transpire:

- Antagonisms growing out of the civil rights movement, counterculture, and/or views of the Vietnam war grew into a horrendously violent civil war during the 1960s, in which over three million young men died; ${ }^{157}$

156. Frederick Hoxie, A Final Promise: The Campaign to Assimilate the Indians, 1880-1920 (Lincoln, NE: University of Nebraska Press, 2001); Snipp, American Indians.

157. Over 600,000 men died in the American Civil War, out of a population of $31,000,000$. The same proportion of casualties 


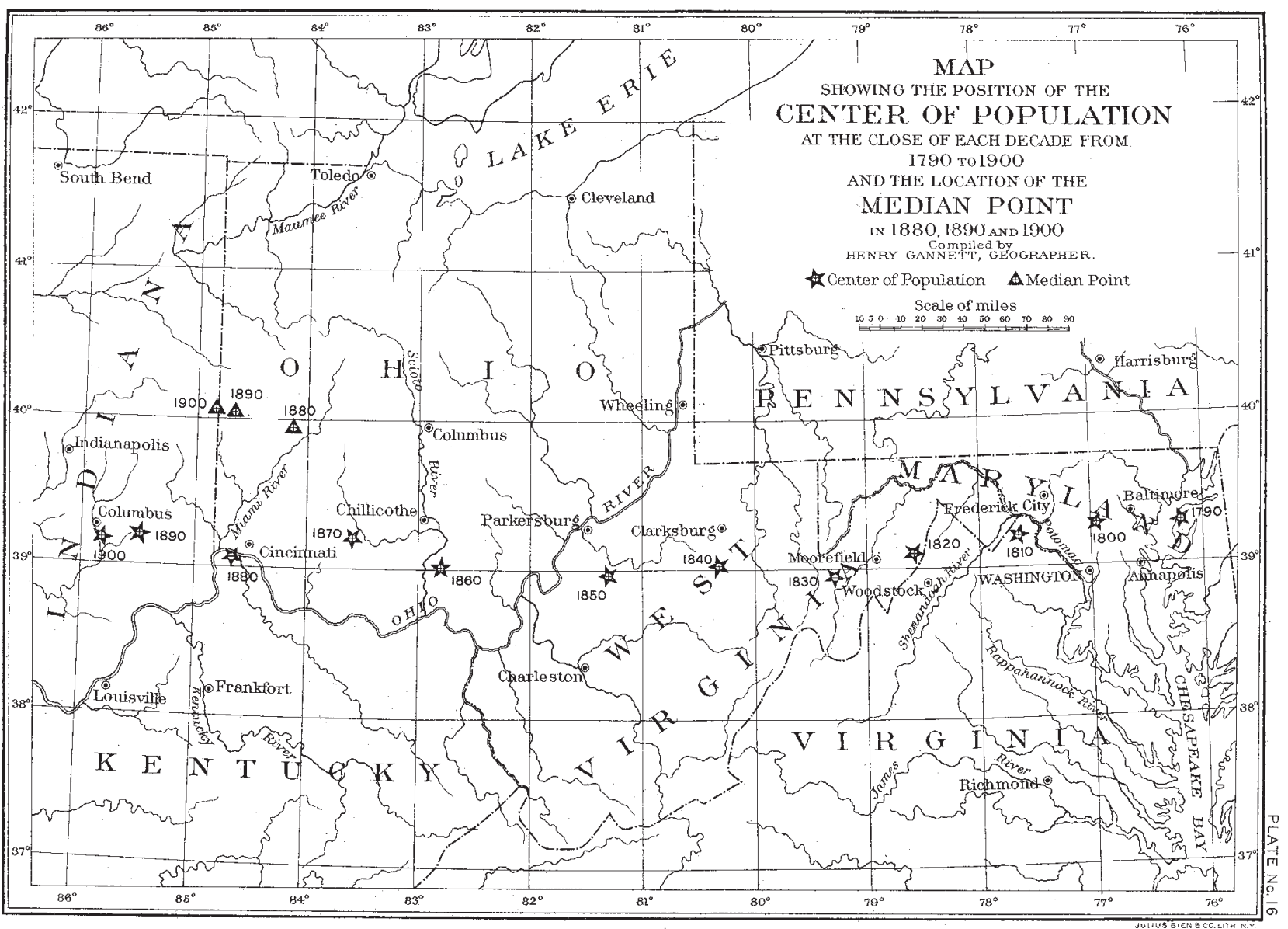

Fig. 3. Center of Population, 1790-1900

Source: U.S. Bureau of the Census, Statistical Atlas (Washington, DC: Government Printing Office, 1903 ), Plate 16.

- African Americans move from second-class status and formal segregation to full legal citizenship, and then lose most of that ground until a majority end up comprising an urban "underclass";

- The United States acquires 1.8 million square miles from Canada or Mexico; ${ }^{158}$

- Immigration increased dramatically after the 1965 immigration law, so that during the $21^{\text {st }}$ century immigrants comprise more than 15 percent of the American population and their children comprise another 15 percent or more;

- U.S.-occupied military bases around the world are declared to be American territories, and the United States goes to war to defend that

(almost 2 percent) implies a mortality rate of well over 3,000,000 for the 1960 population of over $179,000,000$.

158. Alternatively, if one considers relative rather than absolute increases in size, the United States increases in size from its current 3.7 million to over 8 million square miles. declaration. All of their populations are now to be included in census enumerations;

- Middle Easterners, or Muslims, are no longer permitted to immigrate into the United States, and those already here are denied the right to become naturalized citizens and are uniquely subject to certain legal restrictions;

- All illegal immigrants (roughly 12 million at present) are deported, and any land or property that they had acquired is seized or bought at rockbottom bargain rates; and

- Over 50 million Americans move from the state in which they were born, most from rural or suburban areas into cities.

A few of these events are close to reality (the immigration and migration rates, the persistence of deep poverty in some predominantly black urban areas). But of course most have not transpired and will not do so. We offer this list not as anything resembling a prediction or retrospection, but rather as a way to drive home the magnitude of 
the politically-relevant demographic changes encountered by the United States a century ago. And that list, of course, says nothing about industrialization, technological change, foreign policy or any other major changes that also affect census data collection.

Even this rather fanciful counterfactual scenario does not capture the magnitude of the stress that the Census Bureau faced over the decades of transformation. For the first half of our period, it was a weak agency, regularly disbanded and reconstituted with new personnel and no institutional memory. As Superintendent Walker wrote in 1891, "The strain upon the nerves and the vital force of whomsoever is in charge of the census is something appalling.... Taking a Census of the United States under the present system, and upon the existing scale, is like fighting a battle every day of the week and every week for several months." ${ }^{159}$ The community of social scientists, statisticians, demographers, business executives, public officials, advocacy and interest groups, and others who now regularly rely on census data and protect its integrity-though not without controversy and tension-was just beginning to come into existence. So the bureau lacked the protection of a committed constituency. ${ }^{160}$ In addition, for most of the nineteenth century Congress treated census enumeration as an opportunity for partisan patronage, and well into the twentieth century racial scientists sought to use it to bolster their pet theories. So the demographic and political upheaval would have been even more difficult to deal with then than the equivalent alterations suggested by our counterfactual history would be now. 161

By 1940, all of this demographic transformation ceased. The frontier was officially closed. Immigration from all of Asia, extending into what we now call the Middle East, was prohibited. The Supreme Court issued two rulings that set boundaries on who could be deemed "white." Immigration from Europe was cut to a small fraction of its former levels, with most quotas given to Northern European nations. Indians were decimated and either confined to reservations, which were a fraction of their former sizes and a tiny proportion of the original land held by tribes, or incorporated in some fashion into mainstream society. No new states were admitted until the 1950 s. No new territories were acquired. Mexicans remained officially white and were still permitted to migrate across the border for work, but their

159. Qtd. in James Phinney Munroe, A Life of Francis Amasa Walker (New York: Henry Holt and Company, 1923), 197-98.

160. However, see Magnuson, "Making of a Modern Census" on the constituency pressures that it did face.

161. Our thanks, here and elsewhere, to Kenneth Prewitt for giving us the census-eye view of material that we tend to approach from our vantage point as social scientists. movements were increasingly regulated and they were subject to "repatriation" (including American citizens). Internal migration continued, but at lower levels. Southern and border states completed legislating one-drop-of-blood laws for African Americans and put the final touches on Jim Crow segregation. The eugenics movement and scientific interest in racial mixture were losing public respectability in the face of Nazism.

Experiments in racial reorganization stopped when the demographic and institutional transformations of the previous nine decades also ceased. The Census Bureau no longer needed to measure and record racial mixture among blacks, given one-drop legislation. It no longer needed to measure and record mixed parentage and mother tongue among whites, given the 1924 Immigration Act. It no longer was permitted to record members of the Mexican race; there was no such thing. Given Asian exclusion, the Census Bureau no longer needed to add new Asian nationalities to its counts, and in fact was able to delete a few. Given the Indian Reorganization Act of 1934, attention to the racial characteristics of individual Native Americans became less important. The racial order settled on a few mutually exhaustive and exclusive categories-white, Negro, Indian, and several Asian nationalities. Each could be clearly and consensually fixed in both the vertical dimension of status and the horizontal dimension of American-ness. There things remained for several decades, frozen at the moment when the power of anti-black racism and anti-foreigner xenophobia had both reached their peak in modern American history.

\section{CONCLUSION}

But few persons recognize the importance of care in the wording of the census schedules. -Census Director William Steuart

It is possible that, by 2050, today's racial and ethnic categories will no longer be in use. - Migration News, $2004^{162}$

For most of American history, a person's racial classification largely shaped his or her social status, civil rights, economic opportunities, political standing, and legal citizenship. The important task of deciding whether and where new populations fit into the American racial order, along both horizontal and vertical dimensions, involved institutions from the local to the federal level-including the national census.

162. Steuart, "Conduct of the Fourteenth Census," 572; Migration News, "Census, Welfare, California, New York City," University of California, Davis, 22 Dec. 2004. Accessible at: http:// migration.ucdavis.edu/mn/. 
As we have noted, censuses on their own are neither necessary nor sufficient to create (or destroy) group hierarchy, but they play a special role in the construction of racial orders in the four ways we described earlier in this article.

Why These Taxonomies, and Why Did They Start and Stop? A census bureau engages in that construction within a domestic, international, and institutional environment. But macro-level explanations cannot explain why the American racial taxonomy was revised in so many distinctive and inconsistent ways every decade from 1850 to 1930. Nor can macro-level explanations fully make sense of the system that was consolidated by 1940 . Within a deeply racist and xenophobic context, that system defined racial groups in a haphazard way-some by color (blacks and whites), some by nationality (Chinese and Japanese), some by ethnicity and tribe (Indians), and some by ignoring socially recognized ethnicity and color (Mexicans). As we have shown, understanding these particular changes requires looking inside the institution itself at the Census Bureau's struggles over bureaucratic control and autonomy, drive for scientific legitimacy, and ideological commitments about the nature of race.

We see no reason to think that any one or two of these motivations is gaining ascendancy over the other(s). Analysts mostly concur that the Census Bureau has become a more powerful and autonomous agency with the passing decades and centuries, as Appendix Table A2 would suggest. But it never has moved and presumably never will move out from under the scrutiny and intervention of the rest of the executive branch and Congress. Even the Supreme Court has moved into the business of counting the population-in fact, more now than in decades past (e.g., Utah v. Evans, 2002). Similarly, the bureau's level of demographic and statistical sophistication is impressive, and census demographers are tightly connected with their academic and professional peers-but census classification systems are under just as much political pressure as a century ago. Census officials struggle to ignore ideological commitments-their own as well as those of Congress or other actors-but they recognize the impossibility of ever fully doing so. Decisions about racial classification and enumeration presumably will always result from a mixture of politics, science, and ideology; the issues are too important, too complicated, and too fraught to anticipate otherwise.

What macro-level explanations can best do is explain why instability in the census racial taxonomies arose and declined when it did. After all, census categories were quite stable for the five decades before 1850 and the six decades after 1930—-so why the intervening era? The politics of demography provided our answer; before 1850 and after 1930, there was little experimentation in racial classification because demographic pressures could be managed in terms of the existing racial order. That was not the case from the ante-bellum period to the Great Depression.

The Re-emergence of Taxonomic Experimentation: That point opens the issue of the contemporary American census. It is once again increasingly unstable and inconsistent-largely because, as one might expect from the analysis in this article, the United States is once again experiencing considerable demographic change to which it must respond institutionally. The most compelling question about the current era is whether demographic and political pressures are strong enough to undermine the two-dimensional logic of the American racial order-or whether they will, as in the past, mainly rearrange groups' locations in that order.

Five phenomena shape the current era of experimentation in racial taxonomies. Three have to do with the population being classified, and two with the classifiers. The first is a rise in immigration after the 1965 Immigration Act that in some years and some locations rivals the scope of a century ago. As then, immigrants are coming from nations that are not considered to be white or are only marginally so, and the same anxieties about assimilation and foreigners' impact on democratic governance are surfacing. The second phenomenon is the growth of multiracialism both demographically and politically. Rising immigration, the 1967 abolition of antimiscegenation laws (Loving $v$. Virginia 1967), and increased integration in such institutions as the military and universities have created conditions under which racial intermarriage is rising rapidly. The number of interracial couples has grown 7.5 percent annually since $1960 ;^{163}$ as of 2000 , about 14 percent of children living in a married couple family had parents who differed in race. ${ }^{164}$ (Those figures do not include marriages between Hispanics and others, or children with one Hispanic parent.) Simultaneously, a multiracial movement that asserts individuals' right to publicly and officially identify with more than one race or as "multiracial," including on the census, has developed. The third phenomenon is more amorphous, and may best be labeled "identity politics." Among its many features, the relevant one here is that groups-understood as races, ethnicities, or nationalities-are increasingly eager to assert their public visibility, and to demand what they perceive to be their rightful recognition or share of governmental resources.

The other two phenomena have to do with the classifiers, not the classified. Census officials can no

163. ESRI "Trends in the U.S. Multiracial Population from 1990-2000" (ESRI, 2005). Accessible at: www.esri.com/data/ resources/literature.html.

164. Reynolds Farley, "The Declining Multiple Race Population of the United States: The American Community Survey, 20002005," presented at Population Association of America, New York City, 29-31 Mar. 2007. 
longer assert with a straight face that "statistics ... if they are patiently and faithfully collected, judiciously arranged and applied, and wisely digested, ... lead to a more positive knowledge of the real state of things." ${ }^{" 65}$ As late as 1972, a former Bureau director could assert that "the first element in the creed of a statistical agency is a belief in the importance of objective measurement."166 But the Office of Management and the Budget (OMB) now officially recognizes that "the categories [on the U.S. Census] represent a social-political construct designed for collecting data on the race and ethnicity of broad population groups in this country, and are not anthropologically or scientifically based."167 Thus census officials are in the uncomfortable position of seeking to provide demographic precision for a set of categories that they know are invented and changeable, rather than discovered and fixed.

Finally, racial and ethnic groups are now active participants in creating, no longer helpless recipients of, any taxonomic scheme. The degree of helplessness varied in the past, of course, across groups and over time, but the promoters of "mother tongue" and the challengers of the "Mexican race" were the exception rather the rule. By now, active and energetic advisory bodies represent all minority groups, as commonly understood, to the Census Bureau, while members of Congress and advocacy organizations look out for their interests in a way that was inconceivable around the turn of the twentieth century.

These five phenomena are elaborately linked in ways that we cannot develop here. Suffice it to say that in combination, they are having and will continue to have a significant impact on census racial taxonomies. Consider the relevant questions in Figure 4, from the 2000 census.

Several features are distinctive. First, one's population group is self-identified (as it has been since 1970), so there is relatively little risk that a person will be labeled in a way that he or she finds mistaken or offensive. Second, Hispanic ethnicity (but no other) is identified separately from race and antecedent to it, with a combination of nationality, identitybased, and panethnic terms. ${ }^{168}$ Third, everyone (including Hispanics) can choose more than one

165. Francis Lieber, 1836 Memorial to Congress. Qtd. in Magnuson, "Making of a Modern Census," 25.

166. Eckler, The Bureau of the Census, 121.

167. Office of Management and Budget, Revisions to the Standards for the Classification of Federal Data on Race and Ethnicity (Washington, DC: Executive Office of the President, OMB Office of Information and Regulatory Affairs, 1997).

168. Hispanicity returned to the national census in 1970 , when a 5 percent sample was asked if their "origin or descent" were Mexican, Puerto Rican, Cuban, Central or South American, or Other Spanish. The full population was asked about "Spanish/ Hispanic origin or descent" in 1980, with answer categories identifying three nationalities (one of which was "Mexican, Mexican-American, Chicano"). In 1990, additional nationalities appeared as examples of "other Spanish/Hispanic." In short, Hispanic ethnicity on recent censuses encompasses nationality,

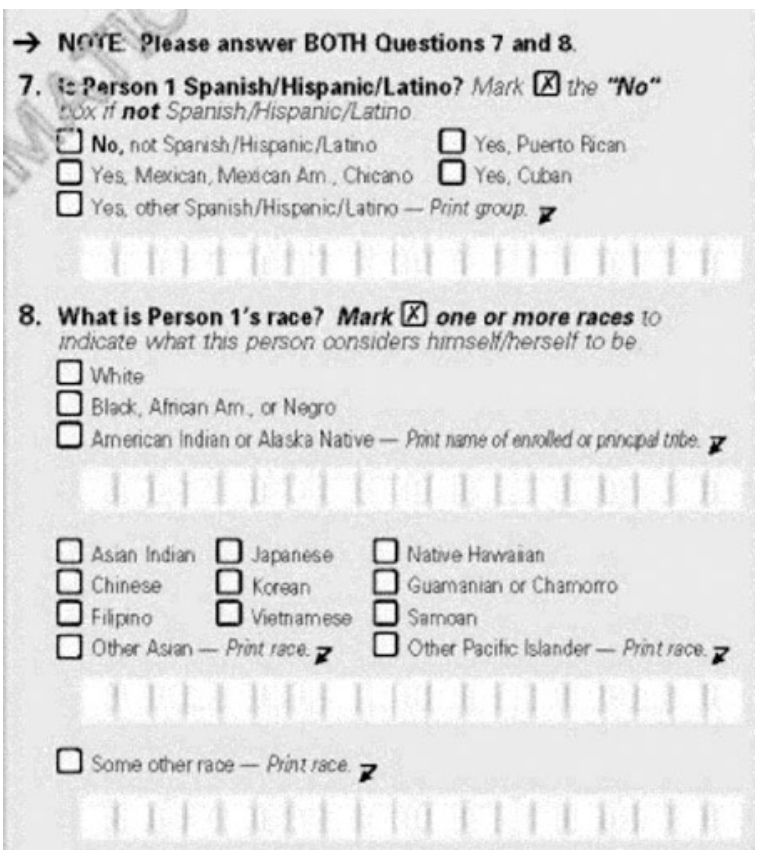

Fig. 4. 2000 Census Form, Race and Ethnicity Source: U.S. Census Bureau, Census 2000 Questionnaire.

race. Fourth, roughly three-fourths of the population are identified by only one color-based term"white"-while tiny fractions of the population are identified by nationality (Native Hawaiian, Guamanian or Chamorro, Samoan). There continues to be no panethnic or racial label for Asians on the census form itself. Uniquely among federal agencies, the Census Bureau was permitted (in 2000) or is required (in 2010) to include "Some other race" as one racial option. In a personal communication to the authors, as one knowledgeable observer has put it, racial categories on the census are a "rat's nest."

Obviously, the census form is still shaped by politics and ideology as much as by analysts' desire for accurate and complete data. Just as figure 1 demonstrates the nation's anxiety about the nationality of European immigrants in 1920, figure 4 demonstrates the nation's current almost complete indifference to Europeans but great concern about Asians and Pacific Islanders. Hispanic advocacy groups and advisory committees prefer to keep Hispanicity isolated from race, and to ask about it first, in order to maximize the number of responses to that question. Asian members of Congress are responsible for the multitude of Asian and Pacific Islander categories, and a Hispanic Representative preserved "Some other race" so that Hispanics would not need to choose one of

panethnicity, continent, political identity ("Chicano"), and a catchall "other." 
the conventional American racial categories. African American advocacy groups influenced, though they did not determine, the OMB's choice of "mark one or more" rather than a separate "multiracial" category. Nevertheless, despite the obvious social constructedness of the categories, all of these items were extensively and carefully pretested before census 2000, along with a variety of alternative formulations and presentations, in order to ensure the greatest possible scientific reliability and external validity.

What remains to be seen is what happens if the demography of the United States continues to change dramatically and if the federal government continues to be buffeted by both advocacy groups and its own recognition of the contingent nature of classification systems. Will the ethnoracial pentagon that most living Americans grew up with-black, white, Asian, Indian, and Latino-crumble? Even the sober and cautious Migration News observed in an uncharacteristic burst of speculation, "It is possible that, by 2050, today's racial and ethnic categories will no longer be in use." After all, the census now permits 126 racial and ethnic combinations-which is way too many to be useful-and there is nothing but OMB's choice to prevent more nationalities (Arab?) or ethnicities (Middle Eastern?) from being added. The system has both too many and too few categories. ${ }^{169}$ But whether demographic change and the political pressures it induces are enough, given the changes in the political climate and in groups' legal standing since the 1960s, to deeply disrupt the American racial order as a whole remains to be seen.

"More Research is Needed:" It always is—but perhaps especially for what we see as a novel arena of investigation. We envision several directions for future investigation, in addition to simply watching to see whether the United States' new round of taxonomic experimentation turns into a genuine upheaval.

First, the subject of this article could be investigated more deeply and broadly. Can anything more be learned about the silences in the census record through further archival research or informed speculation? What influence, if any, did censuses in other nations, newly-acquired territories, or American states have on the national census? What role did courts, state legislatures, pressure groups, experts, foreign governments, and other contextual elements play in changing census practices? How were these census data used?

Second, the political and substantive role of national censuses has only recently been theorized, and much work remains to be done. What determines whether states embrace or shy away from elaborate ethnic and racial classification schemes? Are the logics of Foucaultian discipline, group incorporation,

169. Jennifer Hochschild, "Multiple Racial Identifiers in the 2000 Census, and Then What?" in The New Race Question: How the response to international pressures, bureaucratic stickiness, apportionment, and racial supremacy really distinct, and do they combine differently in particular countries? Can we specify the causal role of census taxonomies, compared with their reflective or reifying role? When do census bureaus attain greater autonomy, and do they use it to pursue scientific rigor or ideological commitments (and when are those sharply separable)? How are censuses' racial data used for purposes of advocacy, policy-making, and representation?

Third, it would be valuable to know how generalizable are the three motivations of politics, ideology, and science for making sense of political actors' choices. Do these three forces explain the behavior of census bureaus in other nations? Of other technological, purportedly neutral service agencies? Of all important bureaucracies? Of all governmental institutions?

Fourth, we need more research into the uneasy relationship around the turn of the twentieth century between what we now call the social construction of race and biologically based assertions of "racial science" and eugenics. Each of these elements of the American racial order has been extensively researched, but seldom with an eye toward determining how both contributed to or were in tension with the politics of creating and maintaining a complex and possibly vulnerable racial order. Similarly, we need more attention to the ways in which the full array of racial groups were simultaneously and mutually constituted, whether through the mechanisms of biology, social construction, political power, norms and beliefs, or something else.

Finally, political scientists in our view have paid insufficient attention to the political implications of demographic and geographic transformation. Research in American political science tends, with notable exceptions, to focus on the national government located in Washington, DC-and that is arguably the least good vantage point for analyzing the upheaval experienced by old and new Americans at present as well as around 1900. After all, a century ago the federal government did not move despite the vast increase in size of the United States, and it did not change its fundamental structures or practices despite emancipation, immigration, exclusion, acquisition, decimation, and conquest. Similarly, immigration and multiracialism now have more impact in North Carolina and California than in Washington, DC. Just as historians of the West upended our traditional Puritan-centered focus on the American founding, so geographers and demographers might usefully shake up the study of American political development.

Census Counts Multiracial Individuals, ed. Joel Perlmann and Mary Waters (New York: Russell Sage Foundation, 2002), 340-53. 


\section{Appendix Table A1. Racial Reorganization on the U.S. Census, 1850-1940}

Information in bold face is on main population schedule.

Information in italics is in enumerators' instructions for main population schedule.

Information in plain text is in tabulations or published documents.

Information inside [brackets] is explanatory.

\begin{tabular}{|c|c|c|c|c|c|c|}
\hline Year & Blacks & American Indians & Whites & Asians & Hispanics & Other and Foreign-born \\
\hline \multirow[t]{3}{*}{1850} & $\begin{array}{l}\text { Black, mulatto in Color } \\
\text { category }\end{array}$ & & & & & \\
\hline & $\begin{array}{l}\text { Tables often combine } \\
\text { mulatto and black }\end{array}$ & $\begin{array}{l}\text { Indians taxed some- } \\
\text { times written in as } \\
\text { "other" }\end{array}$ & - & $\begin{array}{l}\text { Chinese in } 1852 \mathrm{CA} \\
\text { census }\end{array}$ & - & - \\
\hline & $\begin{array}{l}\text { [Separate schedules for } \\
\text { free persons and slaves] }\end{array}$ & $\begin{array}{l}\text { [No enumeration of } \\
\text { untaxed Indians] }\end{array}$ & & & & \\
\hline \multirow[t]{4}{*}{1860} & $\begin{array}{l}\text { Black, mulatto in } \\
\text { Color category }\end{array}$ & & & & & \\
\hline & $\begin{array}{l}\text { Black without admixture; } \\
\text { Mulatto or mixed blood }\end{array}$ & Indian & - & & - & - \\
\hline & & & & Asiatic in CA & & \\
\hline & $\begin{array}{l}\text { [Separate schedules for } \\
\text { free persons and slaves] }\end{array}$ & $\begin{array}{l}\text { [No enumeration of } \\
\text { untaxed Indians] }\end{array}$ & & & & \\
\hline \multirow[t]{3}{*}{1870} & $\begin{array}{l}\text { Black, mulatto in Color } \\
\text { category }\end{array}$ & Indian & White & Chinese & & \\
\hline & $\begin{array}{l}\text { Mulatto: "quadroons, } \\
\text { octoroons, and all } \\
\text { persons having any } \\
\text { perceptible trace of } \\
\text { African blood" }\end{array}$ & & & $\begin{array}{l}\text { Chinese includes } \\
\text { Japanese but not } \\
\text { Hawaiian; Japanese } \\
\text { noted in footnotes }\end{array}$ & - & $\begin{array}{l}\text { State or territory of birth, or country } \\
\text { if outside US }\end{array}$ \\
\hline & & $\begin{array}{l}\text { [No enumeration of } \\
\text { untaxed Indians] }\end{array}$ & & & & \\
\hline
\end{tabular}


Appendix Table A1. Continued

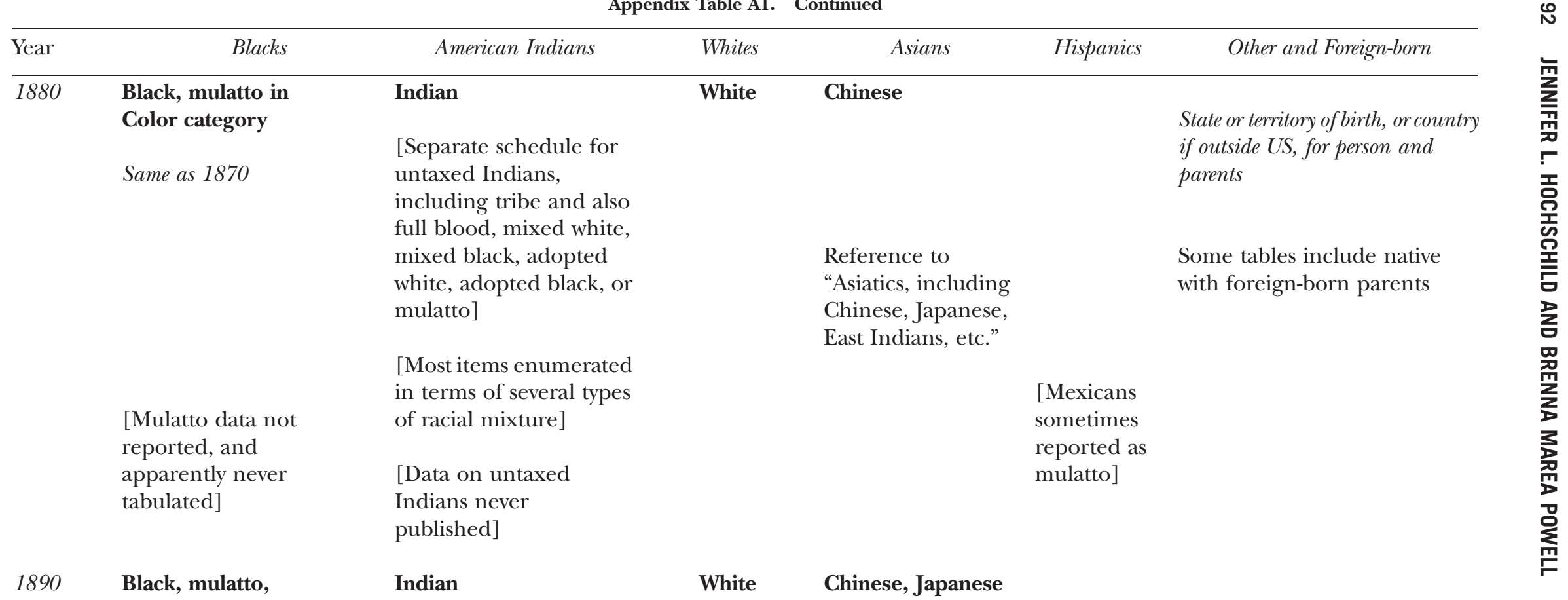

quadroon, octoroon

(category had no

label)

Black: $3 / 4$ or more black

blood

Mulatto: 3/8 to 5/8 black

blood

Ouadroon: 1/ 4 black blood

Octoroon: $1 / 8$ or any

trace of black blood

State or territory of birth, or country if outside US, for person and parents; born abroad of American parents; born at sea; if parent born at sea, nationality of that parent's parent; years in US; naturalized or applied to naturalize 
[3 schedules for

untaxed Indians. All

Tables usually combine all three with black

Tables of "total colored" include "persons of negro descent, Chinese,

Japanese, and civilized Indians"

\section{No specification in "Color or race" category}

Black: negro or of negro descent

Tables of "colored" include "persons of negro descent, Chinese, Japanese, and Indians" include $\%$ of tribe that is

full blood and mixed

blood; one also includes

tribe and white, black,

mulatto, quadroon,

octoroon, Chinese,

Japanese, or Indian]

[5 special volumes published]

\section{No specification}

Indian

[Separate schedule for Indians outside

"civilized society," including tribe, parents' tribe(s), whites or negroes

living with them]

[Fraction of white blood: $0,1 / 2,1 / 4$

$1 / 8$ "or whichever fraction is nearest the truth"]

\section{No specification No specification}

White

Chinese, Japanese

Some tables

include native

whites with native

or foreign

parentage; foreign

white; foreign-born

with American

parents; born at sea
Some tables include native with foreign-born father; native with foreign-born mother; foreign white; foreign-born with American parents; born at sea

\section{No specification}

State or territory of birth, or country if outside US, for person and parents; born abroad of American parents; born at sea; if parent born at sea, nationality of that parent's parent of the same sex; year of immigration to US; years in US naturalized 
Appendix Table A1. Continued

\begin{tabular}{|c|c|c|c|c|c|c|}
\hline Year & Blacks & American Indians & Whites & Asians & Hispanics & Other and Foreign-born \\
\hline \multirow[t]{2}{*}{1910} & $\begin{array}{l}\text { No specification in } \\
\text { "Color or race" } \\
\text { category }\end{array}$ & $\begin{array}{l}\text { No specification } \\
\text { Indian }\end{array}$ & $\begin{array}{l}\text { No specification } \\
\text { White }\end{array}$ & $\begin{array}{l}\text { No specification } \\
\text { Chinese, Japanese }\end{array}$ & No specification & $\begin{array}{l}\text { No specification } \\
\text { Other: write in the person's race }\end{array}$ \\
\hline & $\begin{array}{l}\text { Black: evidently } \\
\text { full-blooded negroes. } \\
\text { Mulatto: all persons } \\
\text { having some proportion } \\
\text { or perceptible trace of } \\
\text { Negro blood }\end{array}$ & $\begin{array}{l}\text { Extremely detailed } \\
\text { tables with many } \\
\text { varieties of racial } \\
\text { mixture among } \\
\text { blacks, whites, and } \\
\text { Indians, along with } \\
\text { tribal mixtures } \\
\text { [Separate schedule } \\
\text { for Indians on } \\
\text { reservations or "in } \\
\text { family groups." Inquiry } \\
\text { includes tribe, parents' } \\
\text { tribe(s), "proportions of } \\
\text { Indian and other } \\
\text { blood," with separate } \\
\text { columns for Indian, } \\
\text { White and Negro } \\
\text { fractions] }\end{array}$ & $\begin{array}{l}\text { Some tables } \\
\text { include native } \\
\text { white of native, } \\
\text { foreign, or mixed } \\
\text { parentage; and } \\
\text { foreign born }\end{array}$ & $\begin{array}{l}\text { Some tables } \\
\text { include Hindus, } \\
\text { Koreans, Filipinos, } \\
\text { Maoris, Hawaiian, } \\
\text { part Hawaiian } \\
\text { Text notes that } \\
\text { Hindus are } \\
\text { ethnically } \\
\text { Caucasian }\end{array}$ & $\begin{array}{l}\text { [Mexicans } \\
\text { sometimes } \\
\text { reported as } \\
\text { mulatto] }\end{array}$ & $\begin{array}{l}\text { State or territory of birth, or } \\
\text { country if outside US, for person } \\
\text { and parents; born at sea; year of } \\
\text { immigration to US; naturalized; } \\
\text { English language ability or } \\
\text { language spoken; mother tongue } \\
\text { of person and parents for } \\
\text { foreign-born }\end{array}$ \\
\hline \multirow[t]{2}{*}{1920} & $\begin{array}{l}\text { No specification in } \\
\text { "Color or race" } \\
\text { category }\end{array}$ & No specification & No specification & No specification & No specification & No specification \\
\hline & $\begin{array}{l}\text { Mulatto and black usually } \\
\text { reported together }\end{array}$ & Indian & $\begin{array}{l}\text { White } \\
\text { Tables similar to } \\
\text { 1910; mixed } \\
\text { parentage specified } \\
\text { by gender of } \\
\text { foreign parent }\end{array}$ & $\begin{array}{l}\text { Chinese, Japanese, } \\
\text { Filipino, Hindu, } \\
\text { Korean }\end{array}$ & $\begin{array}{l}\text { [Mexicans } \\
\text { sometimes } \\
\text { reported as } \\
\text { mulatto and } \\
\text { possibly Indian] }\end{array}$ & $\begin{array}{l}\text { Other: write in the person's race } \\
\text { Queries similar to } 1910\end{array}$ \\
\hline
\end{tabular}

[No separate schedule] 


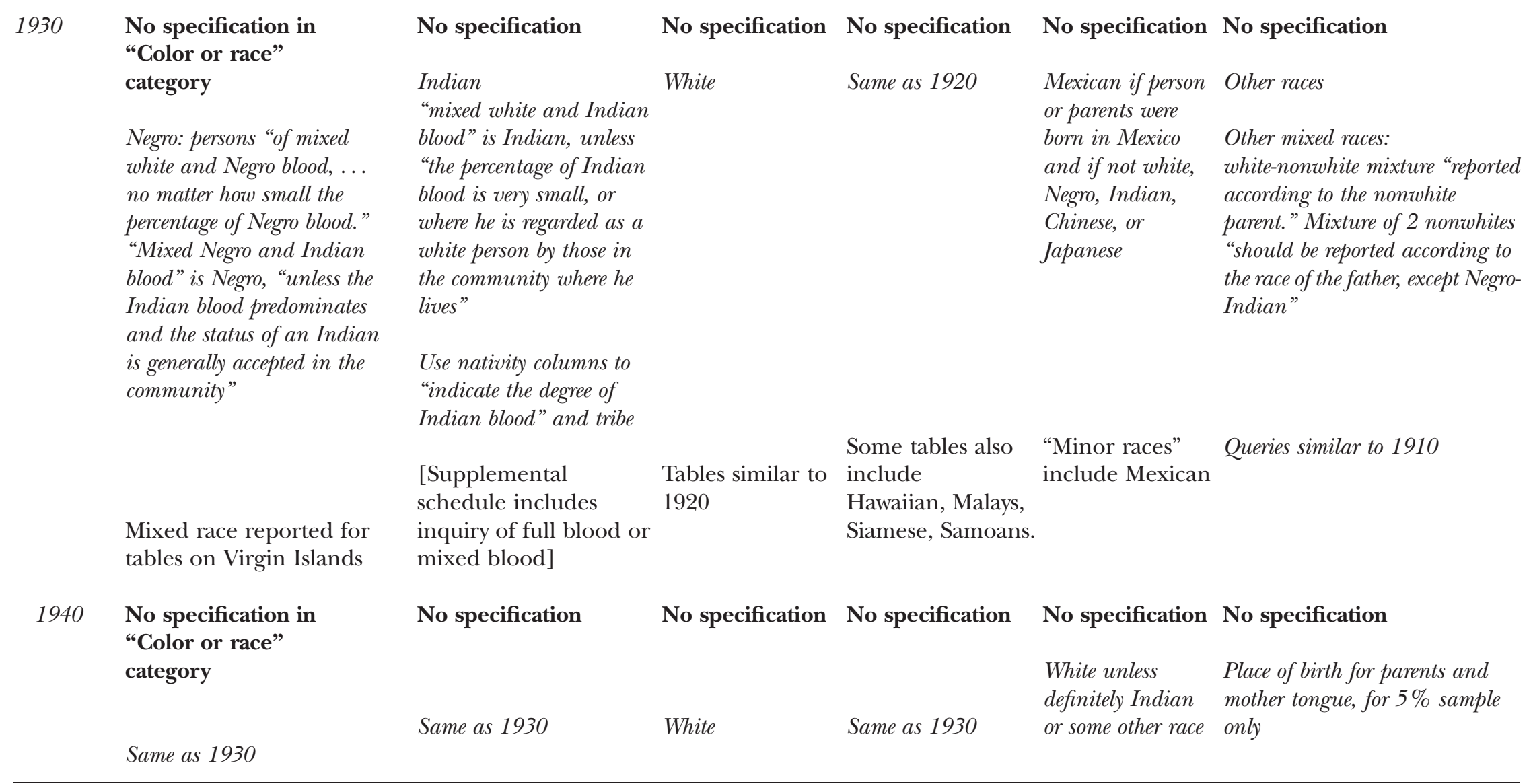

Sources: Census population volumes; U.S. Bureau of the Census, Measuring America; Nobles, Shades of Citizenship, appendix. 
96 JENNIFER L. HOCHSCHILD AND BRENNA MAREA POWELL

Appendix Table A2. Growth of the Decennial Census, 1790-1990

\begin{tabular}{llcrrr}
\hline Census year & $\begin{array}{c}\text { Number of } \\
\text { enumerators per } \\
1,000,000 \text { US } \\
\text { residents }\end{array}$ & $\begin{array}{c}\text { Maximum } \\
\text { size of office } \\
\text { staff }\end{array}$ & $\begin{array}{c}\text { Total pages in } \\
\text { published reports }\end{array}$ & $\begin{array}{c}\text { Total cost in } \\
\text { constant 2006 } \\
\text { dollars (thousands) }\end{array}$ & $\begin{array}{c}\text { Real cost per } \\
\text { capita, in dollars }\end{array}$ \\
\hline 1790 & 167 (est.) $^{*}$ & 0 & 56 & 503 & 0.11 \\
1820 & $124^{*}$ & Unknown & 288 & 2,641 & 0.23 \\
1850 & $139^{*}$ & 160 & 2,165 & 33,274 & 1.19 \\
1860 & $141^{*}$ & 184 & 3,189 & 42,645 & 1.13 \\
1870 & $164^{*}$ & 438 & 3,473 & 49,999 & 1.04 \\
1880 & 630 & 1,495 & 21,458 & 120,879 & 2.00 \\
1890 & 744 & 3,143 & 26,408 & 249,879 & 3.30 \\
1900 & 696 & 3,447 & 10,925 & 276,900 & 3.03 \\
1910 & 764 & 3,738 & 11,456 & 345,639 & 3.13 \\
1920 & 825 & 6,301 & 14,550 & 283,467 & 2.23 \\
1930 & 715 & 6,825 & 35,700 & 457,445 & 3.10 \\
1960 & 889 & 2,960 & 103,000 & 854,729 & 3.96 \\
1990 & 2,051 & 17,763 & $500,000 \#$ & $4,077,170$ & 13.63 \\
\hline
\end{tabular}

* Enumerators were federal marshals' assistants.

+ Population revised to include adjustments for underenumeration in Southern states

\# By 1990, electronic forms of publication (tape, microfiche, CD-ROM, Internet publications) made print pages a poor indicator of census data distributed.

Source: Adapted from Anderson, Encyclopedia of the U.S. Census, 383-84. 